\title{
Enformasyonun Duygu Boyutu: Duygusal Bulaşıcılık Perspektifinden Sosyal Ağlarda Duygu Çalışmaları
}

\author{
The Emotional Dimension of Information: Emotion Studies In Social Network Sites from the \\ Perspective of Emotional Contagion
}

Şeyda Koçak Kurt, Arş. Gör. Dr., Ankara Hacı Bayram Veli Üniversitesi İletişim Fakültesi, E-posta: seydak@gmail.com

https://doi.org/10.47998/ikad.863473

Anahtar Kelimeler:
Duygu,
Duygusal Bulaşıcılık,
Emoji,
Sosyal Ağ,
Facebook,
Twitter.

Keywords:

Emotion,

Emotional

Contagion,

Emoji,

Social Network,

Facebook,

Twitter.

\section{$\ddot{O} z$}

Sosyal ağların dijital teknolojilerle bütünleşmesiyle birlikte kullanıcıların enformasyona erişme araç ve yöntemleri değişmiştir. Bununla birlikte oluşan enformasyon yı̆̆ını içerisinde kullanıcılar, kişisel tercihlerine ve ağların yönlendirmelerine bağlı olarak çeşitli içeriklerle karşılaşırlar. Bu karşılaşma gerçekleşirken, ağlardan yayılan içeriklerin kullanıcılar üzerindeki etkilerinin duygu boyutunun analizi bir gerekliliktir. Çünkü internet sitelerinde yer alan içeriklere kullanıcıların çeşitli emojiler ve duygu reaksiyonları vasıtasıyla tepki verebilmeleri, kullanıcıların enformasyonu edinirken ve değerlendirirken duygularını da bir değerlendirme aracı olarak hesaba kattıklarını göstermektedir. Özellikle Facebook ve Twitter gibi sosyal ağ sitelerinin mimari yapılarının nitelikleri ile paylaşma aracılığıyla dolaşıma sokulan enformasyonun yayılması ve değerlendirilmesinde duygular ön plana çıkmaktadır. Bu bağlamda bu çalışmanın amacı sosyal ağlarda duygusal bulaşıcılık ile ilgili yapılmış uluslararası araştırmaların sistematik bir derlemesini sunmaktır. Çalışmada enformasyonun yayılmasında duygusal bulaşıcılığın etkisinin ne olduğunu belirlemek üzere Facebook, Twitter ve Weibo ağlarında duygular üzerine yapılmış ve Web of Science verilerine göre en çok atıf almış 10 çalışma incelenmiştir. Çalışmada farklı bilim alanlarında yapılan araştırmaların amaçları, desenleri, sonuçları ve önerileri karşılaştırmalı şekilde sunularak hem kişisel hem de kamusal olaylarda kullanıcıların enformasyon edinmede ne tür bir duygusal performans gerçekleştirdikleri analiz edilmiştir. Derlenen makalelerin sonuçlarına göre, sosyal ağların içeriklerinin duygudan azade olmadığı ve birer içerik üreticisi haline gelen kullanıcıların oluşturdukları enformasyonun da duyguları barındırdığı ve yakın ağlar içerisinde yer alan kullanıcıların benzer duygu örüntüleri göstererek birbirlerini etkiledikleri ortaya çıkmıştır.

\section{Abstract}

With integration of social networks into digital technologies, means and ways to acces information have changed for users. Moreover in stack of information that has occured, users encounter various contents, resting on their personal preferences and manipulations of networks. While this encounter is happening, it is essential to analyze emotional dimension of contents' effects on users that spread from networks. Since the fact that users can react to content on websites via various emojis and emotional reactions shows they consider their emotions as an evaluation tool while obtaining and evaluating information. Emotions come into prominence in dissemination and evaluation of information circulated through sharing with qualities of architectural structures of social network sites (SNSs), mainly such as Facebook and Twitter. In this context, aim of this study is to present a systematic review of international studies on emotional contagion in SNSs. In this research, for determining effect of emotional contagion on dissemination of information, 10 articles about emotions on Facebook, Twitter and Weibo networks that have been cited most, according to Web of Science data were examined. In the study, aims, patterns, results ands suggestions of researches in different scientifc fields were presented in a comparative manner, and emotional performance of users in acquiring information in both personal and public events was analyzed. In respect of selected articles' results; it has been revealed that content of SNSs is not free from emotion and information created by users have become content producers also contains emotions, and users in close networks affect each other by showing similar emotional patterns. 


\section{Giriș}

Duygular bireysel olduğu kadar toplumsal hayatın da önemli bir bölümünü oluştururlar. Hareket etmek, dışarı çıkmak anlamlarına gelen Latince bir kelime olan 'emovere' kelimesinden türeyen duygu kavramı (emotion), bireyler, toplumlar, topluluklar arasında hareket halindeki yapısına gönderme yapmaktadır (Ahmed, 2014: 21). Bu bağlamda duygular yalnızca kişiye özel ve psikolojinin alanında yer alan şeyler değil, bireylerin birbirleriyle ilişkilerine ya da toplumlar arasındaki ilişkilere atıf yapan bir yapıya da sahiptir. Dolayısıyla duyguları sabit anlamlara ve belirli bir yerde duran bir yapıya sahip olmalarından ziyade onların karşılıklı etkileşim açısından özelliklerini dikkate alma gerekliliği ortaya çıkmaktadır.

Duyguların hem bireysel hem de toplumsal bağlamdaki bu hareketliliği, duygusal bulaşıcılık kavramına yakından bakmayı gerektirmektedir. Bulaşma kelimesi (contagion), temas (contact) kavramından türemiştir (Ahmed, 2014: 20). Gündelik hayatta bireyler belirli duygu durumlarına sahiptirler ve bu duygu durumları genellikle diğerleri ile olan iletişim ve etkileşimde ön plana çıkmaktadır. Diğer insanların duyguları, bizim duygularımızı doğrudan etkiler (Parkinson ve diğerleri, 2005: 181). Depresif bir ruh haline sahip olan bir kişiyle iletişim kurulduğunda depresif hissetme ihtimali olabilir ya da mutluluk, sevinç gibi olumlu duyguların yoğunlukta olduğu bir ortamda, duygu durumu bu doğrultuda gelişebilir ve değişkenlik gösterebilir. Duygusal bulaşıcılık denilen bu fenomen, psikolojinin temel ilgi alanları arasında yer almakla birlikte, bireylerarası ve topluluklar arası ilişkilerin belirlenmesinde de önemli bir yere sahiptir. Grup duygusal bulaşıcılığını, bir gruptaki insanlar arasındaki duygu durumlarının transfer edilmesi olarak tanımlayan ve bunu 'dalgalanma etkisi' olarak nitelendiren Barsade (2002: 644); çalışmasında duygusal bulaşmanın bireysel düzeydeki tutumlar ve grup süreçleri üzerinde önemli bir etkisi olduğunu ve pozitif duygusal bulaşmanın grup üyeleri arasında iş birliğini geliştirdiği, çatışmayı azalttığı ve görev performansında artış sağladığını gözlemlemiştir.

Duygusal bulaşıcılık, birebir ve yüz yüze ilişkilerde, mimiklerle ya da bedensel eylemlerle gerçekleşerek davranışsal uyumluluğu artırmakta ve bireyler farkında olmadıklarında dahi diğerlerinin duygularını izlemeyi sağlamaktadır (Hatfield ve diğerleri, 1994: 6). Az sayıda insandan oluşan küçük gruplarda etkili olabileceği gibi, aynı zamanda geniş toplumsal ağlarda da kendisini göstermektedir. Bu bağlamda özellikle mutluluğun kitlesel olarak nasıl yayıldığını inceleyen Fowler ve Christakis (2008); 4.739 kişiyi temel alan ve 1983 ve 2003 yılları arasını kapsayan 20 yıllık bir çalışmanın sonucunda; mutlu insanlarla çevrili kişilerin gelecekte mutlu olmalarının daha olası olduğu sonucuna varmıştır. Her bir ilişkinin aynı zamanda toplumsal bir bağ olduğunu söyleyen Fowler ve Christakis (2008: 2); bireylerin mutlu olup olmadığını incelemiş ve zaman içindeki mutluluk değişimlerini gözlemlemiştir. Araştırma, sadece belirli bir zaman dilimindeki duygu durumlarının bulaşıcılığını göstermekle kalmamakta, bununla birlikte toplumsal ağlardaki mutlu insanların diğerleriyle iletişim kurmaya, mutlu olmayanlara göre daha fazla hevesli olduğunu ortaya çıkarmaktadır. Duygular özellikle toplumsal bir role sahiptir: İnsanlar duyguları deneyimlediklerinde birbirlerine gösterme eğilimindedirler (Fowler ve Christakis 2008: 8). Çalışmanın bir diğer önemli özelliği mutluluğun bulaşıcılığının birinci dereceden ilişkilere bağlı olmayışıdır. 'Arkadaş', 'arkadaşın 
arkadaşı' ve 'arkadaşın arkadaşının arkadaşı' şeklinde üç dereceli bir toplumsal ilişkinin temel alındığı ağ analizinde mutlu insanların diğer mutlu insanlardan oluşan büyük kümelerde bulunma eğiliminde olduğu ortaya çıkmıştır. Mutluluğun yayılmasının yakın fiziksel mesafe gerektirdiği ve etkisinin zamanla azaldığı düşünüldüğünde bu sonuçlar daha da dikkat çekicidir (Fowler ve Christakis, 2008: 7).

$\mathrm{Bu}$ bağlamda, bireylerin duygularının değişmesi ve belirlenmesinin yüz yüze ilişkilere bağlı olmaması, günümüzde bireysel ve kitlesel iletişime imkân tanıyan sosyal ağların bu bulaşıcılıktaki rolünü akıllara getirmektedir. Sosyal ağların etkileşime izin veren yapısı, bireylerin ve toplulukların birbirleriyle bu ağlar vasıtasıyla iletişim kurmasını sağlamaktadır. Bu iletişim kurulurken duygular dişarıda bırakılmamaktadır. Çeşitli haber sitelerinin internet sayfalarında yer alan içeriklerinin altında 'emoji'ler yardımıyla paylaşılan içeriğe karşı duyguların seçilebileceği gibi, sosyal ağ siteleri ve uygulamalarının içeriklerine duygu ifadeleri bırakılarak hissedileni iletebilmek mümkün olmaktadır. Bu bağlamda sosyal ağlardan yayılan içeriklerin duygudan bağımsız olduğunu düşünmek mümkün değildir. Teknoloji, yalnızca kullanıcıların duygularını harekete geçirerek duygulanımın ifadesi için bir kanal hizmeti vermemekte; aynı zamanda bu duygulanımın ayarlanmas1, tüketilmesi ve gösterilmesini de etkilemektedir (Serrano-Puche, 2015: 2). Bir tür kamusal yakınlığı (Thrift, 2010: 294) beraberinde getiren yeni medya formları bireysel ve toplumsal düzlemdeki ilişkilerin yeniden düzenlenmesini sağladığı gibi, iletişimin duygu boyutuna imkân vermesi ve aynı zamanda onu dönüştürmesi bakımından ayrıca incelenmeyi hak etmektedir.

$\mathrm{Bu}$ çalışma uluslararası literatürde bu alanda Facebook, Twitter ve Weibo'da yapılan çalışmaları ele almaktadır. Çalışma kapsamında konu ile ilgili araştırmalar incelenmiş, bu araştırmaların özellikleri sistematik derleme yöntemine uygun olarak amaçlarına, yöntemlerine, sonuçlarına ve önerilerine göre kategorileştirilerek mevcut durum değerlendirilmiştir. Sosyal ağların duygu içeren mimari yapıları, kullanıcıların bu ağlarda eriştikleri enformasyonun yayılmasında etkili olan duygu performansları ve duygu yoğunluklu içeriklerin olumlu ve olumsuz sonuçları saptandıktan sonra, derlenen makaleler incelenmiş ve çeşitli öneriler sunulmuştur.

\section{Sosyal Ağların Duyguya İmkân Veren Yapısı}

İnternet teknolojilerinin gelişmesi ve Web 2.0'ın hayatımıza girmesi ile birlikte kullanıcının pasif konumundan çıkarak içerik üretmesi mümkün olmuştur. Böylece kullanıcılar yalnızca tüketici olmaktan çıkmış ve hem üreten hem de tüketen rolüne sahip olarak üre-tüketiciye dönüşmüşlerdir (Toffler, 1980). Bu şekilde içerik üretimine ve değiş tokuşuna izin veren internet tabanlı uygulamaların bu özelliği kullanıcı-türevli içerik olarak adlandırılmaktadır (Kaplan ve Haenlein, 2010: 61). Günümüzde bu özellik, çevrimiçi ve çevrimdışı dünyayı birbirine bağlarken, aynı zamanda bireysel ve topluluk düzeyinde daha geniş bir insan etkileşimine olanak sağlamıştır (Van Dijck, 2013: 4).

2000'li yıllarda sosyal ağların dijital ortamlarda baskın olmasıyla birlikte kullanıcıların enformasyona daha kolay ve hızlı bir şekilde erişmeleri söz konusu olmuştur. 
İnternet her çeşit enformasyona sahiptir ve kişisel ilgili alanları dışında karşılaşılan pek çok farklı enformasyona da erişilmesi mümkün olmaktadır. Bu enformasyon yoğunluğu içerisinde diğerlerinin ne hakkında konuştuklarını bulmanın ve bilmenin tek yolu ise, onların paylaştıklarını kontrol etmektir. Kontrol etme ve enformasyondan mahrum kalmama eylemi bazı kişiler için o denli önemlidir ki; bir şeylerin kaçırıldığı ve yakalanamayacağı inancına sahip olanlara ait olan ve internetsiz kalma korkusunu içeren netlessfobi (Öztürk, 2015; Yıldırım ve Kişioğlu, 2018) denilen teknolojik bir korku türü dahi ortaya çıkmıştır.

Sosyal medyanın bu anlamda dünyayı keşfetme, öğrenme ve anlama şeklimizi dönüştürdüğünü söylemek mümkündür. Ancak aslolan araçlar ve hizmetler değil, insanın paylaşmaya duyduğu bitmez tükenmez hevestir (Hermida, 2014: 6). Dolayısıyla paylaşma sosyal ağlarla birlikte ortaya çıkan bir durum değildir. Ancak sosyal ağların paylaşmanın doğasını hız, içerik, geri dönüş gibi konular açısından önemli derecede değiştirdiği söylenebilir.

Belirli bir çevre ile oluşturulan bu ağlarda kullanıcılar deneyimlerini paylaşmaktan keyif alırlar (Jothi ve diğerleri, 2011: 236). Bu paylaşımlar yapılırken bazı videoların, linklerin ya da yazıların diğerlerinden daha çok paylaşıldığ 1 ve teknolojik anlamındaki tabirle "viral(hızla yayılan)" hale geldiği görülmektedir. Peki bu paylaşımları diğerlerinden ayıran ve bazen yerelde bazen de dünya çapında çok kısa süre içerisinde yayılmasına ve duyulmasına yol açan şey tam olarak nedir?

İnternette hızla yayılan pek çok çalışmayı inceleyen Berger (2013); bunların birbirine bağlandıkları ve ortaklaştıkları noktanın "duygu” olduğu sonucuna varmıştır. Berger'e göre (2013: 97) değer verdiğimizde paylaşırız. Bir şeyin doğru, yanlış, olumlu ya da olumsuz olduğunu bilmenin her zaman yeterli olmadığını ve insan davranışlarını değiştirmediğini söyleyen Berger (2013: 113); tam bu noktada duyguların devreye girdiğini ve içeriklerde vurgulanan duyguların insanların harekete geçmesini sağladığını öne sürmektedir.

Sosyal ağlarda yayılma üzerine yapılmış 39 makaleyi inceleyen Zhang ve Vos (2015), bazı konuların nasıl ve neden diğerlerinden daha hızlı bir şekilde dolaşıma girdiği sorusunun cevabını bulmaya çalışmışlardır. Araştırmanın sonucuna göre; paylaşmaya değer bulunan, duyguları ifade eden, eğlenceli ya da olumlu içeriği olan, haber değerine sahip ve insanların birlikte anılmak istedikleri ürünlere yer veren içeriklerin, sosyal ağlarda daha hızlı bir şekilde dolaşıma girdiği bulunmuştur.

Buzzfeed'in kurucusu Peretti ise (2007: 159); sosyal ağların bulaşıcılığını küresel kapitalizmde bilgisayarların başında oturarak mail gönderen ve internette dolaşan yüz milyonlarca sıkılmış ofis çalışanına bağlamaktadır. Beyaz yaka profesyonellerinin günlerinin yarısını arkadaşlarıyla çeşitli medyalar paylaşarak geçirdiğini söyleyen Peretti, bu duruma Bored at Work Network (BWN - İşyerinde Sıkılanların Ağ 1 ) adını vermektedir. BWN tarafından dağıtılan medyanın "bulaşıcı medya" olduğunu söyleyen Peretti’ye göre (2007: 161), bu medya türü küçük bir şekilde başlamasına rağmen, insanların arkadaşlarıyla paylaşması nedeniyle geniş bir kitleye ulaşmaktadır. Komik e-mailler, şaka siteleri, web tabanlı oyunlar, gülünç video klipler ve politik çağrılar, bu tür 
hızla yayılan içerik örnekleridir. Ona göre bulaşıcı medya en iyi toplumsal perspektiften bakıldığında anlaşılabilir. Bulaşıcı medyanın en önemli özelliği derhal arkadaşlarla paylaşılmak istenmesidir. Paylaşmak ve medyayı tüketmek insanlarda tatmin duygusu oluşturmanın yanı sıra, toplumsal süreçte de memnuniyet yaratmaktadır.

Peretti'nin internetin erken dönemlerine dair bu görüşlerini günümüzde sosyal ağlar açısından incelemek gerekmektedir. Tettegah'a göre (2016: xvi); bu dönemde kullanılan elektronik mail listeleri, tartışma forumları, bloglar, wikiler ve e-postalar yoluyla yalnızca sınırlı bir duygu ifadesini deneyimlemek mümkün olmuştur. Bugün ise sosyal medya siteleri bizlere insan deneyimi ve sesiyle neşe, heyecan, acı ve üzüntü gibi pek çok duyguyu gözlemleme ve yaşama imkânı sunmaktadır. Teknolojinin gelişimine bağlı olarak ortaya çıkan geçmiş ve bugün arasındaki fark; artık duyguları 'anında' yaşayabilme ve gözlemleyebilmenin mümkün olmasıdır (Tettegah, 2016: xvi). Bahsi geçen 'anındalık' sosyal ağların mimari yapısı incelendiğinde daha net görülebilecektir.

\section{Ağlaşmış Kamular ve Mimari Yapıları: Facebook ve Twitter Örnekleri}

Tıpkı fiziksel alanların mimarisi olduğu gibi, sosyal ağlar da etkileşime izin veren doğaları gereği mimari bir yapıya sahiptir. Sosyal ağ sitelerini ağlaşmış kamular (networked publics) kavramı üzerinden inceleyen boyd (2011: 39), söz konusu bu kamusal yapıların özelliğinin ağ teknolojileri tarafından yeniden yapılandırılmış olmaları olduğunu öne sürmektedir. Bir sosyal ağa katılan kişiler genellikle bir profil oluşturmakta ve ardından ağdaki arkadaşlara ve kişilere bağlanarak veya gerçek dünyadaki kişileri ve arkadaşlarını sosyal ağa katılmaya davet ederek bir ağ inşa etmektedirler (Mayheim, 2008: 14). Ancak bu ağ yalnızca yakın çevre ve gündelik hayatta karşılaşılan ya da bilinen insanları içermemektedir. Ağlaşmış kamular, diğer tüm kamular gibi benzer işlevler sunmaktadır - insanları toplumsal, kültürel ve sivil amaçlar için bir araya getirmekte ve insanlara yakın arkadaşları ve ailelerinin ötesinde bir dünyayla irtibat kurmalarında yardımcı olmaktadırlar (boyd, 2011: 40).

boyd ve Ellison'a göre (2007: 42); fiziksel yapılar atomlardan oluşurken, bu tür dijital yapılar bitlerin inşasından oluşmaktadır. Mimari yapılar olarak bitler ve atomların arasındaki fark, ağlaşmış kamuların diğer kamulardan farklı bir şekilde inşa edilmesidir. Ağlaşmış kamuların sağlayıcıları; temel olarak bitlerin varlıkları, bitler arasındaki bağlantılar ve bitlerin ve ağların yeni yöntemlerle insanları birbirine bağlama yolları tarafından şekillendirilmektedir. Ağlaşmış kamular olarak sosyal ağların mimari açıdan dört özelliğe sahip olduğunu söyleyen boyd (2011: 43); bunları 'profiller, arkadaş listeleri, kamuya açık yorum yapma araçları ve akış-tabanlı güncellemeler' olarak kategorilendirmektedir.

$\mathrm{Bu}$ özellikler açısından bakıldığında; 2020 yılının üçüncü çeyreğinde aylık aktif kullanıcı sayısı 2.7 milyar olan ve dünyada en çok kullanılan platform olma özelliğine sahip Facebook (Statista, 2020), 'arkadaşlık' ilişkisi üzerinden diğerleriyle bağlantıda olmayı sağlayan ve bu anlamda dijital ortamda kurulan ilişkilerin 'yakınlık' düzeyini farklı bir boyuta taşıyan bir platformdur. Geleneksel medya ile kıyaslandığında, her bir 
kullanıcısının tek bir çevrimiçi kimlikle (hesap) iletileri paylaşmasını talep etmekte ve bunun çevrimdışı kimlikle uyup uymadığını kontrol etmektedir (Correa ve diğerleri, 2015: 71). Çevrimiçi sosyal ağ uygulaması, kullanıcılara bir fotoğrafla birlikte profil oluşturarak hem çevrimiçi hem de çevrimdışı arkadaşlarla tanışma ve bir araya gelmeyi sağlama ve birbirlerinin profillerini ziyaret etme imkânı sağlamaktadır (Papacharissi, 2009:200).

Pazar ve tüketici verileri konusunda çeşitli raporlar ve analizler yayınlayan Obelo (2020) şirketinin Ekim 2020 verilerine göre Twitter aylık olarak dünya çapında 330 milyon kişi tarafından kullanılmaktadır. Bir blog temelinde kurulan ve başlarda 140 karakterle sınırlı olan içerik paylaşımını içeren Twitter'ın metinsel özelliği, zamanla değişerek görselliğin de kullanıldığı bir mecraya dönüşmüştür. Twitter; Facebook gibi 'kimlik egzersizlerini (Binark, 2005)' şart koşmamakla birlikte kullanıcıların bazılarının anonim olmakla ilgili bir problemlerinin olmadığı görülmektedir. Marwick ve boyd'a göre (2010: 116), Twitter'ın yönlendirilmiş bir arkadaşlık modeli vardır: Katılımcılar, akışlarında 'takip etmek' için çeşitli Twitter hesaplarını seçer ve her birinin kendi 'takipçi' grubu vardır. Ancak bugün gelinen noktada kullanıcılar farklı kategorileri içeren sayfalar (örn; eğlence, mizah, siyaset, vs.) oluşturabilmekte ve o alanda atılan twetleri, tweet sahiplerini takip etmeseler dahi görebilmektedirler.

Birçok toplumsal paylaşım ağı ve Facebook, topluluğa dahil olma işlevini "arkadaşlık” bağı üzerinden kurmaktadır. Buradaki arkadaşlık tanıdık kişilerle olabileceği gibi, profilin kamusal ve açık olmasına bağlı olarak herkesle de kurulabilmektedir. Facebook'un teknik yapısı, kullanıcının profilini istediği kişiye açma, istediği kişiye kapatma imkânı sunmaktadır. Böylece arkadaşı̆̆ı̆ın sınırları kullanıcıların karşılıklı anlaşmalarından ziyade, kullanıcının tekil olarak, paylaşımlar özelinde karşıdakiyle ne seviyede arkadaş olmasını istemesiyle belirlenmektedir. boyd ve Ellison (2007), Facebook temelli bir "arkadaş"lığın, bildiğimiz anlamdakinden farklı olduğunu söylemektedir. Baym'a göre (2010: 145), 'Arkadaşlar' kavramı yanıltıcı olabilir, çünkü buradaki bağlantı günlük yaygın anlamdaki arkadaşlık anlamına gelmek zorunda değildir ve insanların internete bağlanma sebepleri değişiklik gösterebilir. Orta sınıf beyaz yakalı işçilerin Facebook kullanımlarını inceleyen çalışmasında Gregg (2012: 149); iş yaşamının, okulun ve eğlencenin samimi bir ortama evrildiğini, bunun da ilişki kurulan kişinin 'arkadaşlık' mefhumu üzerinden 'eşitliği' çağrıştırması nedeniyle gerçekleştiğini söylemektedir.

Her ne kadar belirli gizlilik ayarları ile Facebook profili kullanıcı tarafından gizlilik sınırları içerisinde kullanılsa da boyd'un ifade ettiği şekli ile bu tür sosyal ağ siteleri kamusal iletişime imkân tanımaları nedeniyle aynı zamanda kamusal bir yapıya sahiptir. boyd'a göre (2011: 45); sosyal ağ siteleri hem insanların kitlesel iletişimine imkân tanıdı̆̆ hem de etkileşim ve enformasyonun sağlanmasında alan yarattığ iç̧in kamusaldır. Bu kamusallık ise ağ teknolojileri tarafından şekillendiği ve düzenlendiği için aynı zamanda ağlaşmıştır.

Bir diğer özellik olan akış tabanlı güncellemelere sahip olması ise bu ağların günlük ve anlık iletişime imkân veren yapısına vurgu yapmaktadır. Bu yapı, geçmişle bağlantılandırılabileceği gibi, tam şu anın bilgisine sahip olunmasını sağlamaktadır. 
(Papacharissi, 2009: 208). Facebook ve Twitter'ın paylaşım ve katkı yapmayı sağlayan yapısı sayesinde geçmişte, şimdi ya da gelecekte iletişim kurulabilmektedir. Bu özelliği ile zaman boyutunun farklı şekillerde kullanılması mümkün olmakta ve her halükârda 'anında' iletişim gerçekleştirilebilmektedir. Bu noktada bahsi geçen 'anındalık' etkisinin oluşmasını sağlayan ve enformasyonun paylaşımı ve dolaşımına katkı sunan 'meme' ve 'emoji' faktörlerine yakından bakmak gerekmektedir.

\section{Meme / Caps Kültürrü}

Sosyal medyanın nüfuz ettiği bir kültür, duygulanım bulaşıcılıklarının yayılması ve çoğalması için verimli bir zemin sağlar; bu çoğalma için birincil araç 'meme'lerdir (Onge, 2019: 187). "Meme" kelimesi ilk olarak Dawkins'in "Gen Bencildir" (2004) kitabında geçmektedir. Çağdaş insanın evrimini anlatmak için geni temel alan Dawkins, genin evrimin açıklanmasında temel olarak ele alınmasının yetersizliğinden bahsetmekte ve kültüre vurgu yapmaktadır. Genin bir tür çoğaltıcı görevi görerek nesilden nesile aktarılabilmesi gibi, başka çoğaltıcı ve eşleyicilerin de olduğunu söyleyen Dawkins (2004: 311), bir kültürel iletim birimi ya da bir taklit birimi düşüncesini taşıyan bir isim vererek, Yunanca "mimeme"yi kullanmıştır. Sonrasında ise "gen" gibi tek heceli bir sözcük kullanmak istediğini belirterek, Fransızca meme (kendi) kelimesini kullanmaya başlamıştır.

Genel olarak taklit yoluyla ilerleyen meme'leri, Dawkins genlerin üç önemli özelliği ile karşılaştırır: Uzun ömürlülük, kopyalama sadakati ve üretkenlik. Dawkins'e göre (2004: 315); uzun ömürlülük üzerinde fazla durulmaması gereken bir konudur. Çünkü bazı meme’ler uzun süre dolaşımda kalıp aktarılabileceği gibi çok kısa ömürlü de olabilirler. Kopyalama sadakati ve üretkenlik ise bir meme'in sahip olması gereken önemli özellikler arasındadır. Meme'in temeli, bir fikrin bir başkasına anlatılması ve fikir beğenilirse beyinden beyine aktarılarak çoğaltılmasına dayanmaktadır. Bir "düşünce memi", bir beyinden diğerine iletilebilecek bir varlık olarak tanımlanabilir (Dawkins, 2004: 319).

Günümüzde internette dolaşan ve Türkiye'de kullanılan ismiyle “caps"lerin özellikleri arasında; çok hızlı şekilde yayılmaları, uzun ömürlü olmasalar bile üzerlerinde değişiklikler yapılarak ve kopyalanarak tekrar dolaşıma sokulmaları ve üretkenliğe katkıda bulunmaları yer almaktadır. Hatta emoji'lerin meme'lerin ilk örneklerinden olduğunu söyleyenler de vardır (Kırık ve Saltık, 2017: 103). Ancak zaman içerisinde meme'ler şekil ve içerik açısından değişiklik göstermiş, görseller üzerinde oynanarak ve yazılar eklenerek genellikle mizahi amaçla kullanılmıştır. Internet meme'leri ilk olarak 4Chan isimli sitede yayılmış ve fenomen haline gelmişlerdir (Tekrin, 2016: 576). Meme'lerin hızlı bir şekilde yayılmasının temeli ise küresel bir dil kullanmasına bağlanmıştır (Kırık ve Saltık, 2017: 104). Meme'ler ve caps'ler internetin bulaşıcı doğasının en önemli örnekleri arasındadır. Sampson'a göre (2012: 2); bu çeşitli bulaşıcı modellerle ekonomik kriz, toplumsal etki, inovasyonlar, moda ve hatta insan duygularının bile tıpkı bir virüs gibi ağlar arasında evrensel olarak yayıldığı anlaşılmaktadır.

Peretti (2007: 160); "meme" ile ilgili olarak; "eğer "meme" kendiliğin tekrarlanması fikri ise, bulaşıcı medya bedendeki meme'dir. O, insanların paylaşabildiği medya olarak bedenleşmiş bir fikirdir" demektedir. E-postaların ya da hızla yayılan mesajların ortak 
özelliklerinden biri Peretti'ye göre (2007: 161); orijinal oluşturucuya herhangi bir ücret ödenmek zorunda kalınmamasıdır. Çünkü yaymak için diğer insanların sunucuları ve ağları kullanılmaktadır. Ayrıca bulaşıcı medyanın bir fikrin en basit formunu sunması gerekmektedir. Süslü tasarımlar, ilave içerik ya da ikincil özellikler medyayı daha az bulaşıcı hale getirir. İlave olan her şey "veri yükü"ne sebep olur, bu da projenin daha yavaş yayılmasına neden olur. Taşınabilir ve sonsuz çoğaltılabilir olması bulaşıcı medyanın başka bir özelliğidir. Paylaşmak ve çoğaltmak ne kadar kolaysa, bulaşıcı fikrin gerçekleşme potansiyeli de o kadar yüksektir ve bulaşıcı olup olmayacağının tahmin edilmesinin zor olduğu bu medya projelerinin çoğu kazara oluşturulur.

\section{Bir Duygu Dili Olarak Emojiler}

Emoji kelimesinin orijinali Japonca'dır. Buna göre e "resim", moji de "harf, karakter" anlamlarına gelmektedir. Bu şekilde bakıldığında emojinin "resim-yazı" şeklinde tanımlanabileceği söylenebilir. 2015 yılında Oxford Sözlüğü yılın kelimesi olarak bir emojiyi seçmiştir. Günlük hayatta pek çok kişi tarafından sıklıkla kullanılan (Ail "(face with tears of joy)"un bir kelime olmamasına rağmen seçilmiş olması epey ilgi çekmiştir. Danesi'ye göre (2017: 6), bir kelimeden ziyade bir piktogramın (resimyazı), yılın kelimesi olarak seçilmesi ve buna geleneksel literatüre bağlı olan akademisyenler, öğretmenler ya da dilcilerin hiçbir itirazının olmayışı, insan iletişiminde ve hatta insan bilincinde dikkate değer bir paradigma değişimine işaret etmektedir.

İlk emoticonlar (emoji + icon) olan :( ve :) 1982 yılında, Carnegie Mellon's School of Computer Science'ta görevli bir profesör olan Scott E. Fahlman tarafindan kullanılmıştır. Fahlman'ın amacı; ciddi konuşmaların yer aldığı paylaşımlar ile şaka içerenleri birbirinden ayırmaktır (Rodrigues ve diğerleri, 2017: 393). Emoticonlar yüz ifadeleri [Batı tarzı; örn; ;)], soyut kavramlar, duygular ve hisleri (örn; <3) içeren yeniden temsillerdir. Diğer emoticonlar ise doğrudan bakıldığında görülebilir [Doğu tarzı;örn; $\left(* \wedge .^{* *}\right)$ ] (Rodrigues ve diğerleri, 2017: 393).

Emojilerin hayatımıza girişi uzun bir geçmişe sahip olmasa da gün geçtikçe daha fazla insan tarafından kullanılmakta ve sayıları her geçen gün artmaktadır. Emojilerin ayrıca farklı ülkelerin dillerine, kültürlerine göre farklı semboller şeklinde ortaya çıktığ 1 görülmektedir. Danesi (2017: vii), bu durumun alfabeler nedeniyle sınırlanan sosyo-politik ideolojileri ortadan kaldırarak kültürlerarası iletişime imkân sağladığını öne sürmektedir.

Emojilerin Ekim 2011'de iOS'a ve Temmuz 2013'te pek çok Android platformuna dahil edilmesinin ardından emoji kullanımında ciddi bir sıçrayış olmuştur. (KimuraThollander ve Kumar, 2019: 2). Instagram ve Google'ın arama kısımlarına emojileri dahil etmesiyle, kullanıcılar kelimelere ihtiyaç duymadan aradıklarını emojiler vasıtasıyla bulmuşlardır. Mart 2015'te, Instagram servislerinde yer alan paylaşımların yaklaşık yarısı emojilerden oluşmaktadır ve kullanıcılar enformasyon paylaşımında ve kişisel ifadelerinde kelimelerden çok, çeşitli duygulara karşılık gelen emojileri kullanmayı tercih etmişlerdir (Instagram, 2015). 2017 tarihli bir istatistiğe göre (Emojipedia, 2017), Facebook'ta kullanıcılar birbirlerine günlük 60 milyondan fazla emoji göndermektedir. Özellikle Facebook'un Dünya Emoji Günü olan 17 Temmuz'u kutladığı günde ise kullanıcılar Facebook'un Messenger uygulaması üzerinden 5 milyardan fazla emoji 
göndermiştir.

Sadece küçük dijital ikonlar değil, 'lingua franca' (ortak iletişim dili) olarak da görülen emojilerin kullanımının yaygınlaşmasıyla birlikte önemi de giderek artmaktadır (Hurlburt, 2018: 15). Bugün gelinen noktada ten renkleri de katıldığında toplam 3136 adet emoji kullanılmaktadır (Unicode, 2020). Emojilerin kullanımında kültürlerarası farklılık temel olarak alınan kriterlerden biridir. Farklı kültürlerde farklı anlamlara gelebileceği ihtimaline karşılık olarak, emojiler belirlenirken kimseyi gücendirmemek temel argüman olarak alınmaktadır (Guntuku ve diğerleri, 2019:233). Emojilerin demokratik kullanımıyla ilgili yaptıkları araştırmalarında Sutton ve Lawson (2017), diller ve kültürler için ortak bir emoji oluşturma platformunun kurulması gerektiğini söylemektedir. Bu bağlamda toplumda dezavantajlı olarak görülen grupları da içine alan emojilerin üretilmesine yönelik çalışmalar yapılmaktadır.

Emojilerin yalnızca duyguları ifade etmesinin dışında başka işlevleri olduğunu ortaya koyan çalışmalardan biri Ellis (2018) tarafından yapılmıştır. Ellis'e göre (2018); insanlar sosyal medyada duygularını ifade etmenin bir aracı olarak emojileri kullanırken aynı zamanda işin içine bir çeşit aldatmacayı da katabilmektedir. Goffman'ın (2017: 13) yüz çalışması olarak ifade ettiği yüz-yüze görüşmede zor olabilecekken, sosyal medyada duyguları örtebilmek ya da başka bir duyguya sahipmiş gibi davranabilmek kullanıcılar için çok daha kolaydır. "Böylece temel gerçekleşmiş duygusal ifadelerin hafifletilmiş seçimi (negatif önyargılar) iletişimi kolaylaştırır. Önceden öngörülmüş olanı tam olarak temsil etmeyebilir, ancak istenen etkinin belli bir biçimini mümkün k1lmaktadır" (Ellis, 2018: 23). Bu duruma 'deneyimin emojileştirilmesi' (emoticonisation of experience) ismini veren Ellis'e göre (2018: 24-25) emojiler hissedilen duygunun ifade edilmesinin yanında, duygunun karmaşıklığını azaltmak, duyguları saklamak, açıklama yapmak ve somutlaştırmak (ifadenin müphemliğini azaltmak) gibi amaçlarla kullanılarak hem duygusal ifadeyi artırmayı hem de ifadenin karmaşıklığını azaltmayı sağlamaktadır.

Sosyal medyada bireysel kullanıcılar duygularını kamusal olarak görünür hale getirir ve 'arkadaşlarını' buna tanık olmaya ve bunu paylaşmaya davet ederler. 1982'den itibaren 'emoticon'lar ya da 'smiley'lerin e-postalara ve mesajlara eklenmesi, önemli derecede resmileştirilmiş ve evrensel olarak uygulanabilir olan kolektif bir duygusal dil oluşumunun kapısını aralamıştır (Frevert, 2018: 38).

\section{Araştırmanın Amacı ve Soruları}

Araştırmanın amacı, sosyal ağların duyguya imkân tanıyan yapısal özelliklerini ve enformasyonun paylaşılmasında ve yayılmasında etkili olan duygu içeren faktörleri değerlendirmek ve mevcut durumu ortaya koymaktır. Bu amaç doğrultusunda araştırma soruları aşağıdaki şekilde belirlenmiştir:

- Araştırmaların yayın yılları nelerdir?

- Araştırmaların alanları nelerdir?

- Araştırmaların amaçları nelerdir? 
- Araştırmaların yöntemleri nelerdir?

- Araştırmaların bulgularından elde edilen önemli sonuçlar nelerdir?

- Araştırmaların sonuçlarından çıkan öneriler nelerdir?

Sorulara cevap verilirken 'sosyal ağlarda duygu'yu içeren uluslararası literatürde yapılmış çalışmaların duygusal bulaşıcılığı hangi konular çerçevesinde ele aldığı, incelenen çalışmalarda enformasyonun edinilmesi ve yayılmasında duygunun etkisinin ne olduğu ve kullanıcıların verileri toplarken araştırma etiğinin nasıl oluşturulduğuna bakılarak, araştırmaların benzerlikleri ve farklılıkları ortaya konulmuştur.

\section{Araştırma Deseni ve Yöntemi}

Sosyal ağlarda duygunun enformasyonun dolaşımına, paylaşımına ve bireyler arasındakiiletişimenetürden etkilerinin olduğunuinceleyen araştırmalarınyapılandırılması ve sonuçlandırılması arasındaki süreçleri ortaya çıkarmayı amaçlayan bu çalışmada sistematik derleme yöntemi kullanılmıştır. Sistematik derleme, belirli soruları yanıtlamak için ilgili çalışmaları kapsamlı bir şekilde tanımlamayı amaçlamayı ve sonuçlara ulaşırken bunu dikkate alarak her çalışmanın geçerliliğinin değerlendirilmesini içermektedir (Petticrew ve Roberts, 2006: 39). Bu araştırmada "sosyal ağlarda duygular" ile ilgili uluslararası literatürde yapılmış çalışmaları belirleyip değerlendirmek amaçlanmıştır.

Sistematik derleme içeren bir araştırma kapsamlı ve aynı zamanda seçici olmalıdır (Sümer, 2011: 223). Buna göre sistematik derlemede; amacın açık bir şekilde belirlenmesi, araştırmaya dahil edilen makalelerin belirlenmiş kriterlere göre seçilmesi, seçilen makalelerin ana özelliklerinin tanımlanması ve makalelerden elde edilen bilgiler ile çıkarıma gidilmesi gerekmektedir (Milar'dan akt. Alkan, 2017: 3-4). Bu bağlamda, araştırmanın evreni ve örneklemi belirlenmiş, verilerin toplanmasının ardından araştırmanın yapısı oluşturulmuştur.

\section{Çalışma Evreni ve Verilerin Toplanması}

Çalışmanın evrenini sosyal ağlarda duyguyu temel alan araştırmalar oluşturmaktadır. Belirlenen araştırma sorularına bağlı olarak 2012 ve 2018 yılları arasında yapılmış araştırmalar incelenmiştir. Web of Science (WoS) veri tabanından "emotional contagion" ve "social media" kavramları birlikte aratılarak çevrimiçi bir tarama yapılmış, sosyal ağlarda enformasyonun paylaşılması ve yayılmasında duygusal bulaşıcılığın etkisini inceleyen çalışmalara ulaşılarak veri seti elde edilmiş ve derlenmiştir. Tarama sonucunda 83 adet makaleye ulaşı1mıştır.

Sosyal bilimler alanında daha küçük çaplı araştırmalarda, meydana geldiği birimleri temsil eden örneklemlerin seçimine dayanan olasılık temelli olmayan örnekleme türlerinden amaçlı örnekleme (Koç Başaran, 2017: 489-490) başvurularak, araştırmada çalışılan problemleri aydınlığa kavuşturacak zengin bilgi içeren çalışmalar seçilmiştir. Çalışmalar bu bağlamda en çok atıf alandan en az atıf alana doğru sıralanmış ve Facebook, Twitter ve Weibo'yu temel alan ve hakemli bilimsel dergilerde yayınlanmış ilk 10 İngilizce 
makale uluslararası literatür açısından değerlendirmeye alınmış ve homojen (benzeşik) örneklemeye gidilerek araştırma sınırlandırılmıştır. Buna göre çalışmalar;

- 2012-2018 yı1ları arasında yayınlanmış olması,

- Sosyal ağları ve duygusal bulaşıcılık kavramlarını içererek sosyal ağlarda duygu konusunu temel alması,

- Alanda en fazla atıf verilen ilk 10 makale olması kapsamında araştırmaya dahil edilmiştir.

İncelenen araştırmalar bilimsel alanları, incelenen sosyal medya ağları, kuramsal ve etik yaklaşımları, sonuçları ve önerileri açısından değerlendirilmiştir.

\section{Araştırma Bulguları ve Tartışma}

Araştırmada değerlendirmeye alınan 10 makaledeki tekil yazar sayısı 3, toplam yazar sayısı ise 31' dir. Çalışmada atıf sayıları, yayın yılları, amaçları, yöntemleri, sonuçları ve önerileri temel alınarak analiz edilen makalelerin iletişim, siyaset bilimi, bilişim, ağ ve internet çalışmaları, sosyoloji, psikoloji, yazılım mühendisliği gibi farklı bilimsel alanlarda yapıldığı görülmüştür. Araştırmalar büyük verilere odaklanması sebebiyle sosyal ağ analizi, metin analizi ve duygu analizi gibi meta veri analizi yöntemlerini kullanmışlardır.

Tablo 1. Kramer ve diğerlerinin (2014) makale deseni

\begin{tabular}{|c|c|c|c|c|}
\hline$\underline{\text { Atuf }}$ & Makale İsmi & $\underline{\text { Alan }}$ & $\underline{\text { Amac }}$ & Öneriler \\
\hline 2620 & $\begin{array}{l}\text { - Experimental } \\
\text { evidence of massive- } \\
\text { scale emotional con- } \\
\text { tagion through social } \\
\text { networks }\end{array}$ & $\begin{array}{l}\text { - İletişim ve } \\
\text { Enformasyon } \\
\text { Bilimi }\end{array}$ & $\begin{array}{l}\text { - Facebook Haber } \\
\text { Kaynağındaki duy- } \\
\text { gusal içerik miktarı } \\
\text { değiştirilerek, birey- } \\
\text { ler arasında yüz yüze } \\
\text { etkileşim dışında duy- } \\
\text { gusal bulaşmanın olup } \\
\text { olmadığını test etmek }\end{array}$ & $\begin{array}{l}\text { - Veriler kamusal sağlık } \\
\text { alanında kullanılabilir. }\end{array}$ \\
\hline 2014 & $\begin{array}{l}\text {-Adam D. I.,Kramer, } \\
\text { •Jamie E. Guillory, } \\
\text { •Jeffrey T. Hancock }\end{array}$ & $\begin{array}{l}\text { - Duygu } \\
\text { Analizi }\end{array}$ & $\begin{array}{l}\text { Sonuc } \\
\text { - Facebook'ta } \\
\text { başkalarının duyguları, } \\
\text { bizlerin duygularını } \\
\text { etkiler ve sosyal ağlar } \\
\text { aracıllı̆ıyla büyük } \\
\text { ölçekli bulaşmalar söz } \\
\text { konusudur. Duygusal } \\
\text { bulaşmanın olması için } \\
\text { yüz yüze iletişime gerek } \\
\text { yoktur. }\end{array}$ & $\begin{array}{l}\text { Ayrıca çevrimiçi } \\
\text { mesajların duyguları } \\
\text { etkilemesinin çevrimdışı } \\
\text { davranışlara etkisi in- } \\
\text { celenmelidir. }\end{array}$ \\
\hline
\end{tabular}


Sosyal ağların duygusal yapısını ve insanların paylaşma ve reaksiyon verme şekillerini nasıl etkilediğini ortaya çıkarmaya çalışan bir çalışma, Cornell ve California Üniversiteleri tarafından ortak bir şekilde yapılmıştır. Kramer, Guillory ve Hancock'un (2014) çalışması sosyal ağlardaki duygu durumlarını ve değişimlerini ele alması açısından her ne kadar özgün olsa da çalışmada verileri kullanılan yaklaşık 700.000 Facebook kullanıcısının durumdan haberdar olmayışı, kullanıcıların bilgilerinin izinsiz kullanılması ve aynı zamanda duygu durumlarının haberleri olmadan manipüle edilmesi etik sorunlar olarak ortaya çıkmıştır. Ancak çalışma Facebook'ta başkaları tarafindan ifade edilen duyguların diğer kullanıcıların duygularını etkilediğine ve sosyal ağlar üzerinde büyük çaplı bir bulaşma olduğuna dair deneysel kanıtlar sunması açısından çok önemlidir.

Facebook kullanan kişiler üzerinde yapılan deneyde, yazarlar, Haber Kaynağı (News Feed) bölümünde yer alan duygusal içeriklere müdahale ederek, duygusal bulaşıcılığın yüz yüze iletişimin olmadığı ortamlarda ne şekilde işlediğini bulmaya çalışmışlardır. Araştırmanın sonucuna göre, haber kaynağındaki paylaşımlarda yer alan olumlu ifadeler azaltıldığında, insanlar olumlu paylaşımlarını azaltarak, negatif paylaşımlar yapmaya yönelmişlerdir. Negatif ifadeler azaltılarak daha olumlu paylaşımlara maruz kaldıklarında ise, olumlu paylaşımlar yapma eğiliminde olmuşlardır. Kramer ve diğerlerine göre (2014: 8788); bu sonuçlar, Facebook'ta başkaları tarafından ifade edilen duyguların bizim duygularımızı etkilediğini ve sosyal ağlar üzerinden büyük çaplı bir bulaşma olduğuna dair deneysel kanıtlar sunduğunu göstermektedir. Bir diğer sonuç ise; geçerli varsayımların aksine, yüz yüze iletişim ve sözsüz ipuçlarının duygusal iletişim için kesinlikle gerekli olmaması ve diğerlerinin olumlu deneyimlerini gözlemlemenin, insanlar için olumlu bir deneyim inşa etmesidir (Kramer ve diğerleri, 2014: 8788).

Çalışma, yüz yüze iletişimi gerektirmeyen internet yoluyla etkileşimde, duyguların geniş ölçekte dağılımını göstermesi açısından önemlidir. Yukarıda da bahsedildiği gibi özellikle Facebook'un 'arkadaşlık' üzerinden kurduğu bağlantıda olma hali, kullanıcıların gün içerisindeki ruh hallerinin karşılaştıkları içeriklere göre değişebileceği anlamına gelmektedir. Bu değişim ise kullanıcıların tanıdıkları ya da tanımadıkları kişiler tarafından gerçekleştirilebilir.

Sonuçları açısından önemli olmakla birlikte, etik açısından incelendiğinde çalışmanın yöntemi ve yapılış şekli pek çok eleştiriye maruz kalmasına sebep olmuştur. Kramer ve diğerleri (2014: 8789); makalenin "etik"liği ile ilgili şu ifadelere yer vermişlerdir: "Çalışma, Facebook'ta hesap açan tüm kullanıcıların uymayı kabul ettiği ve bu araştırma için onanmış rızayı oluşturan Facebook Veri Kullanımı Politikası ile tutarlıdır”. Buna göre; Facebook'a üye olmak, bu tür araştırmalarda denek olarak kullanılmayı kabul etmek anlamına gelmektedir. Bu şekilde "etik endişeleri” bir cümle ile geç(iştir)en yazarlar, Facebook News Feed takımından Daniel Schafer, Faceook Core Data Science Team'den Cameran Marlow, Moira Burke ve Eytan Bakshy’ye teşekkür ettikleri çalışmalarında, Facebook ile anlaşmalı olmalarından dolayı herhangi bir sorun ile karşılaşmayacaklarını düşünmüşlerdir. Çalışmada gizlenen ya da öne çıkarılan paylaşımlar ve kullanıcıların karşılaştıkları içeriklere yer verilmemiş, siyasi (seçim davranışlarını kontrol etme) ve ekonomik (marka ve ürün tüketimine yönlendirme) belirsizlikler içermesine bağlı olarak akademik camiada yankı bulmuş ve makalenin yayınlandığı dergi PNAS'ın editörü 
makalenin başlangıcına bir düzeltme yazısı koymak durumunda kalmıştır.

Mark Zuckerberg'ün ardından gelen ikinci isim olarak anılan COO Sheryl Sandberg, bir açıklama yapmış ve yaşananlardan dolayı üzgün olduklarını söyleyerek özür dilemiştir (Newman, 2014). Bu olay, Facebook'un "Veri İlkesi Politikası"nı değiştirmesine sebep olmuş ve platforma kaydolunduğunda her türlü verinin işlenmesi ve kullanılmasının kabul edilmesini şart koşan bir yapıyı beraberinde getirmiştir. Sampson ve diğerlerine göre (2018: 2); deney, açık bir şekilde dünyayı bir araya getiren, ancak tüketici verilerini dikkatlice ve etik olmayan bir şekilde toplamak ve açıça bu tür büyük çaplı manipülasyonlar yapmaktan para kazanmak için bunu yapan kurumsal bir sosyal medya kültürünü ortaya çıkarmıştır.

Tablo 2. Brady ve diğerlerinin (2017) makale deseni

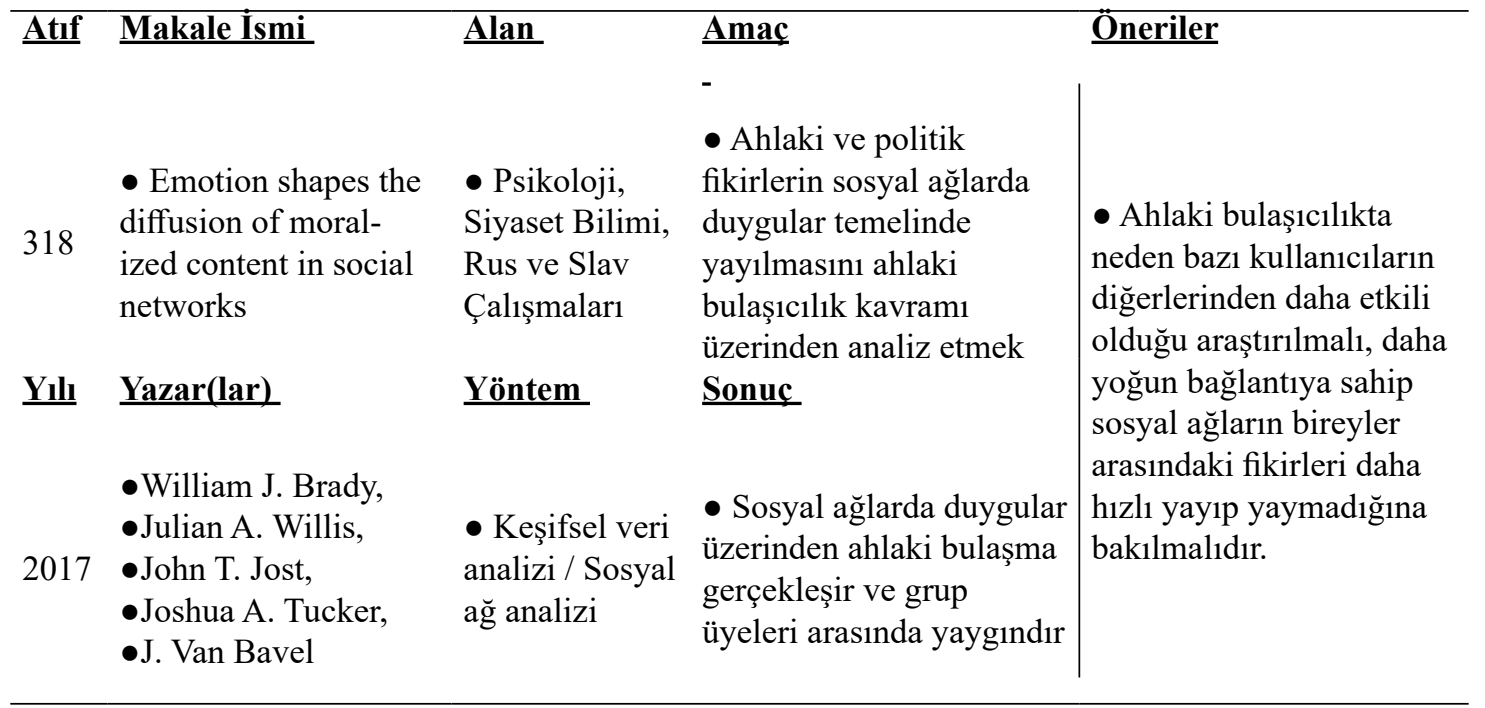

Toplumsal normların gelişmesiyle bağlantılı olarak ele alınan ve 'ahlaki duygular' kategorisine konulan, kişisel ilgilerden ziyade başka bir ülkede gerçekleşen adaletsizliği kınama gibi duygu durumlarını inceledikleri çalışmalarında Brady ve diğerleri (2017), sosyal ağlarda ahlaki duyguların yayılmasının, ahlaki olmayan duygulara göre daha yoğun olduğu sonucuna varmışlardır. Twitter'daki içeriklerin incelendiği çalışmada duygunun sosyal ağlardaki ahlaki içeriklerin yayılımını şekillendirdiğinden bahseden yazarlar, bu durumu 'ahlaki bulaşıcılık' kavramı altında değerlendirmiştir. Silah kullanımı, eşcinsel evlilik ve iklim değişikliğini içeren üç adet başlık altındaki politik tartışmaları inceleyen Brady ve diğerleri (2017: 7317); çevrimiçi etkileşimde bulunan kişilerin, paylaştıkları enformasyonların yayılmasında duygunun etkisinin ne olduğunu bulmaya çalışmışlardır.

Bunu yaparken, Twitter içeriklerini 'ahlaki dil', 'duygusal dil' ve 'ahlaki-duygusal dil' içermelerine göre üç farklı kategoriye ayırmış ve her bir konu başlığını muhafazakâr ve liberal görüş çerçeveleri içerisine dahil etmişlerdir. Çalışmanın sonucunda tweetlerde ahlaki-duygusal dilin kullanımının yoğunlukta olduğu ve insanların sosyal 
ağlar aracılığıyla ahlaki ve politik fikirlere maruz kaldıkları, sosyal ağları daha yoğun kullandıklarında sosyal etki ve grup kutuplaşmasına açık olduklarını bulmuşlardır. Çalışma toplumsal yaşam içerisinde farklı fikirlere sahip kişilerin sosyal ağlarda karşı karşıya gelmesi bağlamında duyguların etkisini göstermesi açısından önemlidir. Sosyal ağların kutuplaştıran yapısını inceledikleri çalışmalarında (Conover ve diğerleri, 2011) Twitter'ın özellikle retweet özelliğinin siyasi olarak motive olmuş bireyler üzerinde etkili olduğunu ve enformasyon akışında kışkırtıcı bir role bürünmelerini sağladıklarını belirtmişlerdir. Kamusal siyasi tartışmaların yoğunlukla gerçekleştiği bir platform olarak Twitter bu bağlamda benzer fikirli kişileri bir araya getirmekte ve bir 'filtre baloncuğu' (Pariser, 2011) oluşturarak karşıt fikirlerle karşılaşma ihtimalini düşürmektedir. Kullanıcılar karşıt fikirlerle karşılaştıklarında ise Brady ve diğerlerinin (2017) çalışmasında olduğu gibi ya kendi duygularını devreye sokarak ya da bulundukları balondaki duygu yoğunluğunun etkisi altına girerek var olan siyasi önyargılarını güçlendirmektedir. Yardi ve boyd'a göre (2010: 8) Twitter'daki bu tür deneyimler ve etkileşimler, siyasi anlamdaki önyargıları pekiştirerek kutuplaştırma sorununu şiddetlendirmeye hizmet etmektedir.

Brady ve diğerlerinin (2017) çalışmasına etik açıdan bakıldığında; araştırma verileri toplanırken, tweetlerini gizlemeyen kullanıcıların içeriklerinden faydalanıldığı belirtilmiş ve kamuya açık tweetler üzerinde analiz yapıldığ 1 görülmüştür. Ancak yeni medya etiği açısından bakıldığında, kullanıcının paylaştı̆̆ı içeriklerin herkes tarafından görülebilir olması aynı zamanda bir araştırmada kaynak olarak kullanılmasına izin verdiği anlamına gelmemektedir. Bu durum, bu araştırmanın da etik açısından sorunlu olduğunu ortaya çıkarmaktadır.

Tablo 3. Ferrara ve Yang'ın (2015) makale deseni

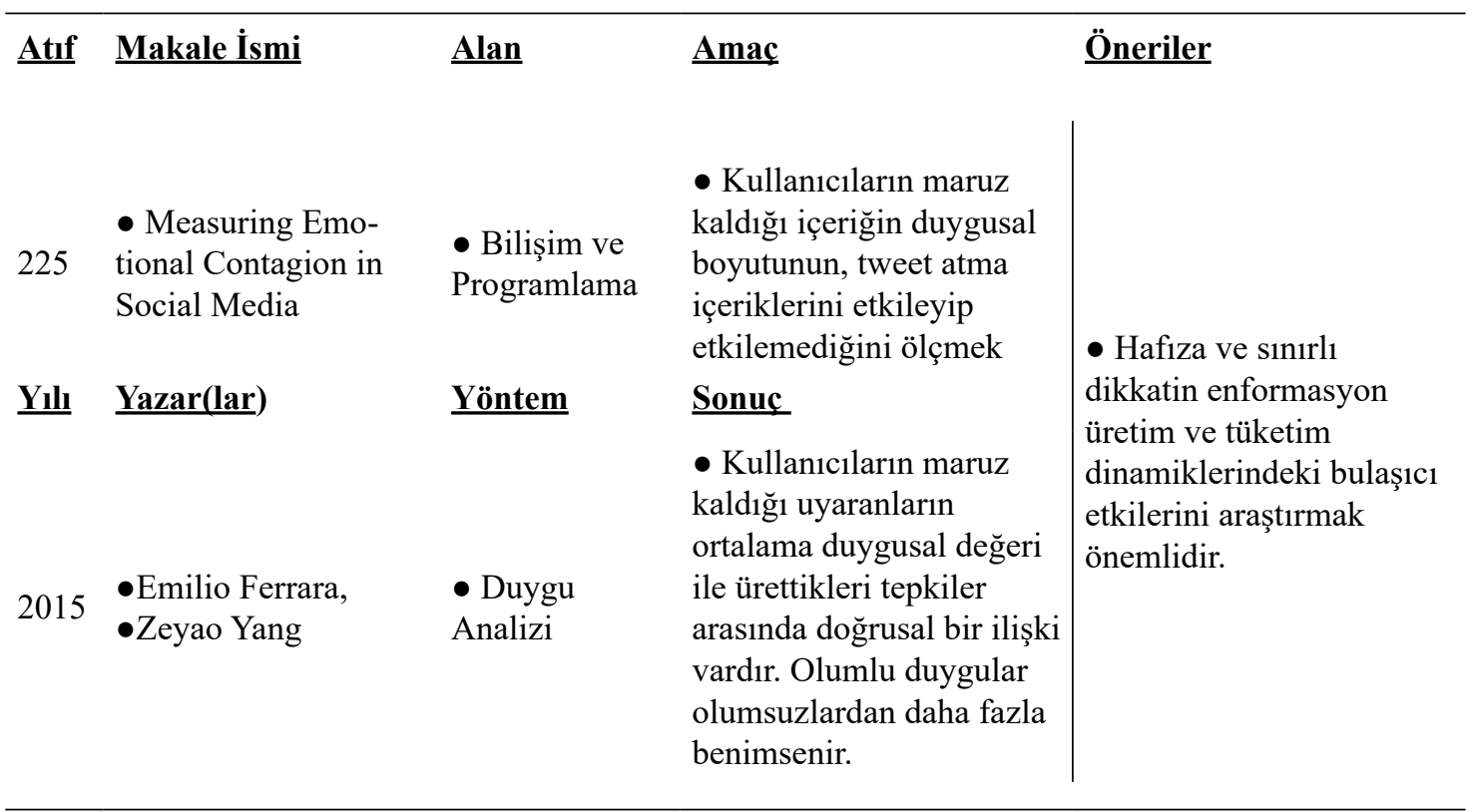

Sosyal medyadaki duygusal bulaşıcılığı ölçmeyi amaçlayan bir diğer çalışma Ferrara ve Yang'a (2015) aittir. Kramer ve diğerlerinin (2014) çalışmasını eleştirerek başlayan 
yazarlar, Twitter içeriklerinin biçimlenmesinde duygusal bulaşıcılığın rolünü bulmaya çalıştıkları araştırmalarında kullanıcıların gördükleri içeriklere kesinlikle müdahalede bulunmadıklarını vurgulamışlardır. 2014 yılının Eylül ayı içerisinde bir haftalık bir zaman diliminde 3800 kullanıcı tarafindan paylaşılan tweetleri inceleyen yazarlar, kullanıcıların paylaşım yapmadan önce gördükleri içeriklere bağlı olarak duygu durumlarını değiştirip değiştirmediklerini analiz etmişlerdir.

Duygu analizi yaptıkları çalışmalarında, kullanıcıların önüne düşen içerikleri duygu açısından olumlu, olumsuz ve nötr olarak kategorize etmişler ve bu içerikler ile kullanıcının paylaştığı içeriğin duygusunu karşılaştırmışlardır. Kullanıcıların maruz kaldığı uyaranların ortalama duygusal değeri ile ürettikleri tepkiler arasında doğrusal bir ilişki olduğunu belirten yazarlar, kullanıcıları daha fazla şüpheci olanlar ve daha az şüpheci olanlar şeklinde ikiye ayırmışlardır. Buna göre daha fazla şüpheci olan kullanıcıların olumsuz duyguları benimseme oranı, daha az duyarlığa sahip olanlara göre daha düşük çıkmıştır. Ancak araştırmanın sonucu açısından önemli olan olumlu duyguları benimseme oranlarıdır. Genel olarak, olumlu duyguların benimsenmesi olumsuz duygulardan daha yüksek olarak bulunmuştur. Çalışma, kullanıcıların paylaşım yapmadan önce maruz kaldıkları içeriğin tamamını okudukları varsayımına dayandığı için bu yönüyle eksiktir denilebilir. Her ne kadar kullanıcıların karşılaştıkları içeriklere müdahale edilmemiş olsa da kullanıcılar bir araştırmanın nesnesi olduklarının farkında olmamaları sebebiyle, bazı etik sorunların doğduğu söylenebilir. Ancak yazarlar Twitter API uygulamasını kullanarak topladıkları kamuya açık içeriğin Twitter'ın hizmet kullanım şartları ile uyumlu olduğunu ve elde ettikleri veriyi kamu ile paylaşmadıklarını belirtmişlerdir.

Tablo 4. Del Vicario ve diğerlerinin (2016) makale deseni

\begin{tabular}{|c|c|c|c|c|}
\hline$\underline{\text { Atıf }}$ & Makale Ísmi & $\underline{\text { Alan }}$ & $\underline{\text { Amac }}$ & $\underline{\text { Öneriler }}$ \\
\hline 219 & $\begin{array}{l}\text { - Echo Chambers: } \\
\text { Emotional Contagion } \\
\text { and Group Polariza- } \\
\text { tion on Facebook }\end{array}$ & $\begin{array}{l}\text { - Hesaplamalı } \\
\text { Sosyal } \\
\text { Bilimler }\end{array}$ & $\begin{array}{l}\text { - Sosyal ağlardaki } \\
\text { duygusal durumun, grup } \\
\text { dinamiklerine katılımı } \\
\text { etkileyip etkilemediğini } \\
\text { belirlemek }\end{array}$ & \\
\hline 2016 & $\begin{array}{l}\text { Yazar(lar) } \\
\text { - Michela D. Vicario, } \\
\text { - Gianna Vivaldo, } \\
\text { - Alessondro Bessi, } \\
\text {-Fabiana Zollo, } \\
\text { - Antonio Scala, } \\
\text { - Gudio Caldarelli, } \\
\text {-Walter Quattrocioc- } \\
\text { chi }\end{array}$ & $\begin{array}{l}\text { - Duygu } \\
\text { Analizi }\end{array}$ & $\begin{array}{l}\text { Sonuc } \\
\text { - Toplulukların } \\
\text { duygusal davranışları, } \\
\text { kullanıcıların yankı odası } \\
\text { içindeki katılımından } \\
\text { etkilenmektedir. Daha } \\
\text { aktif kullanıcılar komplo } \\
\text { teorilerine bağlı olarak } \\
\text { olumsuz duygulardan } \\
\text { daha çok etkilenmektedir. }\end{array}$ & $\begin{array}{l}\text { - Çalışmada herhangi bir } \\
\text { öneriye yer verilmemiştir. }\end{array}$ \\
\hline
\end{tabular}

Facebook'taki kullanıcılar üzerine yaptıkları çalışmalarında Vicario ve diğerleri (2016), kullanıcıların, sistemlerine bağlı olarak enformasyonları seçmek için kutuplaşmış 
gruplar içinde yer aldıklarını betimleyen bir yaklaşım olan yankı odaları oluşturma eğiliminde olduklarını bulmuşlardır. Toplulukların duygusal davranışlarının yankı odası içindeki katılımlarından etkilendiğini belirten yazarlar, daha yüksek katılımın olumsuz duygulara daha fazla maruz kalmaya sebep olduğunu söylemektedirler. Ortalama olarak daha aktif kullanıcılar, daha az aktif olanlara göre olumsuz duygulara daha hızlı kayma eğilimi göstermişlerdir. 73 adet İtalyan Facebook sayfasında gerçekleştirilen çalışmada bilimsel ve komplo teorisini içeren enformasyonun olduğu sayfaları kullananların enformasyonu paylaşmada yankı odaları etkisine ne derece maruz kaldıkları bulunmaya çalışılmıştır. Yanlış enformasyonun yayılmasında neyin daha etkili olduğunu analiz eden Del Vicario ve diğerlerine göre (2016: 2); her iki grupta yer alan kullanıcıların duygusal davranışları topluluk içindeki katılımlarından etkilenmektedir ve Facebook ortamı, özellikle kutuplaşmış toplulukların veya yankı odalarının ortaya çıkması için uygundur. Duygu analizi yaptıkları çalışmalarında yazarların çalışmasının çarpıcı yönü ister bilimsel kanıtlara ister komplo teorisine dayansın, sayfalarda yer alanların duygusal bulaşıcılıktan etkilenmesi ve benzer duygusal davranış değişiklikleri göstermesidir. Araştırmada Facebook'un kendi uygulaması olan API'nın kullanıldığı ve kamuya açık olan verilerin analizi yapıldığı belirtilmektedir. Diğer araştırmalarda olduğu gibi, bunda da kullanıcıların rızaları olmadan araştırmanın nesnesi olarak kullanıldıkları görülmektedir.

Tablo 5. Schroeder'in (2014) makale deseni

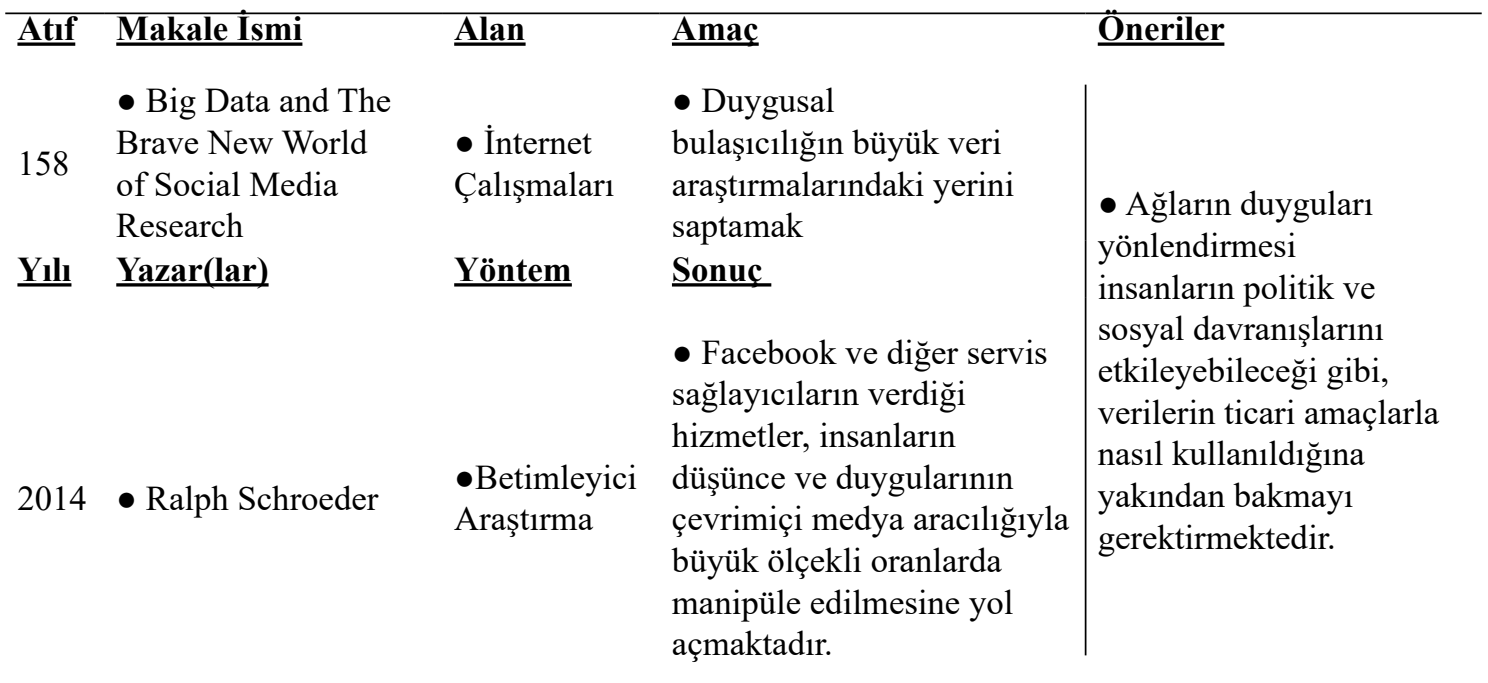

Schroeder'in çalışması (2014), Kramer ve diğerlerinin çalışmasını (2014) temel alarak eleştirel sorular yönelten bir diğer çalışmadır. Büyük veri araştırmalarının etik boyutunu temel alan tartışma, özgür iradenin, deterministik bilimsel bilginin büyümesiyle ne ölçüde uyumlu olduğuna dair önemli olan büyük resmin gözden kaçtığı eleştirileriyle başlamaktadır. Büyük veri analizlerinin mevcut veri kaynaklarının doğası gereği hem etkili olduğunu hem de bir tür kısıtlanmaya sebep olduğunu belirten Schroeder (2014: 1); büyük verinin kullanımının kaçınılmaz olduğunu söylemekle birlikte enformasyonun nasıl kullanılabileceğini, olasılıklarını, tehlikelerini ve her şeyden önce sınırlarını belirlemenin yollarını aramaktadır. 
Büyük verinin tanımının yapılmasının ardından, bu tür çalışmaların gerçekleştirilmesinde sınırların ne olması gerektiğini vurgulayan Schroeder (2014: 9), sosyal ağlarda bulunan kullanıcıların bilgilerinin ticari amaçlarla kullanımı, politik ya da sosyal davranışlarının yönlendirilmesi gibi yaklaşımların çeşitli etik problemler doğmasına yol açtığını belirtmekte ve araştırma etiğini sorgulaması sebebiyle diğer araştırmalardan farklı bir noktada durmaktadır.

Tablo 6. Baker'ın (2012) makale deseni

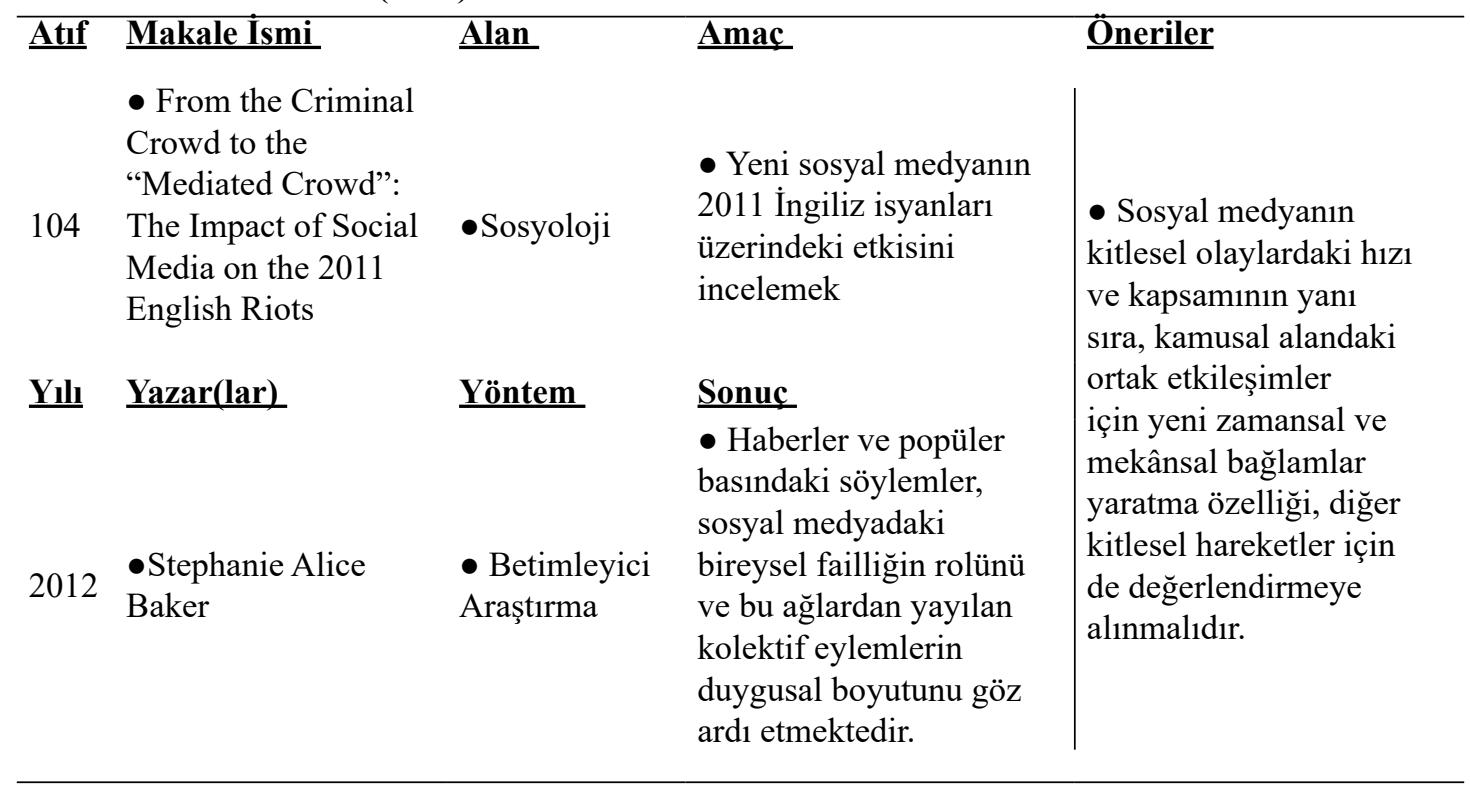

2011 yılında İngiltere'de gerçekleşen isyanlarda sosyal ağların etkisini inceleyen Baker (2012), haberlerde ve popüler basında çıkan isyanlarla ilgili söylemlerin, sosyal medyadaki bireysel faillik rolünü göz ardını ettiğini belirtmektedir. Ona göre geleneksel basın, isyanların ortaya çıkmasında sosyal ağların huzursuzluğu katalize ettiğine dair spekülasyonlar çıkararak, politik retoriğin görünmez kılınmasına yol açmaktadır. Geleneksel ve sosyal medya arasında bir karşılaştırmaya giden Baker (2012: 46), sosyal ağlarda kitlesel hareketlenmeye yönelik davranışlarda bulunanların, geleneksel basın tarafından suçluluk ve yoksunluk polemiklerine maruz bırakılarak kriminalize bir söyleme hapsedildiğini belirtmektedir. Baker'a göre (2012: 49); sosyal ağlar bu tür ayaklanmaların gerçekleşmesinde demokratik bir işlev görmektedir.

Sosyal ağların toplumsal olaylarda 'aracılı bir kalabalık' oluşmasına katkı sağladığını belirten Baker (2012: 46); bireysel failleri bu tür kolektif eylem biçimlerine girmeye motive eden belirli duygusal dinamikleri kavramak için sistematik deneysel bir araştırmanın gerekli olduğuna işaret etmektedir. Ayaklanma gibi olaylarda sosyal ağların kalabalık oluşturmaya elverişli yapısının, medya tarafından kriminalleştirilmeden değişim ve dönüşüme elverişli yapısının vurgulanması gerektiğini belirtmektedir. Baker'ın çalışması bu anlamda sosyal ağların demokratik bir ortam oluşmasındaki olumlu katkısını ön plana çıkarmaktadır. Ancak yine de Baker ağlardan yayılan duygusal içeriğin her zaman olumlu gelişmelere yol açmayabileceğini, bu nedenle geleneksel kitle iletişim araçlarının bu ağlardan yayılan duygu yoğunluklu enformasyonu görmezden gelmemesi 
gerektiğinin altını çizmiştir.

Tablo 7. Gerbaudo'nun (2015) makale deseni

\begin{tabular}{|c|c|c|c|c|}
\hline$\underline{\text { AtIf }}$ & Makale İsmi & Alan & $\underline{\text { Amac }}$ & Öneriler \\
\hline$\underline{\text { Yll }}$ & $\begin{array}{l}\text { - Rousing the } \\
\text { Facebook Crowd: } \\
\text { Digital Enthusiasm } \\
\text { and Emotional } \\
\text { Contagion in The } \\
2011 \text { Protests in } \\
\text { Egypt and Spain } \\
\text { Yazar(lar) }\end{array}$ & $\begin{array}{l}\text { - Dijital } \\
\text { Kültür }\end{array}$ & $\begin{array}{l}\text { - Facebook'un aktivist } \\
\text { eylemlerde yarattığ } 1 \\
\text { duygusal diyalog ortamını } \\
\text { analiz etmek }\end{array}$ & $\begin{array}{l}\text { - Sosyal medya } \\
\text { aktivizminin hızı, } \\
\text { hayal kırıklığı döngüsü }\end{array}$ \\
\hline 2016 & -Paolo Gerbaudo & $\begin{array}{l}\text { - Nitel ve } \\
\text { Nicel Analiz }\end{array}$ & $\begin{array}{l}\text { - Facebook'ta yöneticiler } \\
\text { ve kullanıcılar arasında } \\
\text { duygusal bir diyalog } \\
\text { kurulmuş ve oluşan } \\
\text { dijital coşku ile } \\
\text { duygusal bulaşma süreci } \\
\text { yaratılmıştır. }\end{array}$ & $\begin{array}{l}\text { siyasi sinizm durumunu } \\
\text { güçlendirebilir. }\end{array}$ \\
\hline
\end{tabular}

Sosyal ağların toplumsal hareketlere katkısının incelendiği bir başka çalışma Gerbaudo'ya aittir. Gerbaudo (2015), Misır ve İspanya'da 2011 yılındaki protestoların gerçekleşmesinde Facebook'un etkisini ele almakta ve sosyal ağların yalnızca duyguları yönlendirmekle kalmayıp, aynı zamanda harekete geçmeye de elverişli bir ortamı yarattığını söylemektedir. Facebook sayfalarının yöneticileri ve sayfaya gelen kullanıcılar arasındaki olaylara dönük duygusal geri bildirim döngüsü, ortak bir etkinlik ve güç algısını besleyerek, yüz binlerce insanı önceden çok az hazırlık yaparak eyleme geçmek için harekete geçirmede etkili olmuştur (Gerbaudo, 2015: 256). Aynı şekilde Gerbaudo Twitter'ın kitlesel hareketlenmede rolünü incelediği çalışmasında (2014: xiv), sosyal medya kanallarının, internetteki katılımcıların ortaklaşa paylaşılan semboller etrafında toplandıkları ve hayal kırıklığına uğrama, öfke ve daha iyi gelecek umuduyla karışan duygusal enerji biriktirdikleri bir yer durumuna geldiğini belirtmektedir. Bu kanalların her ne kadar sokağa çıkılmasında çok önemli olmasa da sokağa çıkıldıktan sonra eylemlerin yayılmasında ve kitlesel desteğin toplanmasında oldukça önemli olduğunu belirten Gerbaudo (2014: xv); bu anlamda sosyal ağların demokratik ve devrimci bir yapısının olduğunu söyleyenlerin aksine, bu mecraların yeni bir siyasal katılım kültürüne imkân sağladığını vurgulamaktadır. Ona göre (2014: xii); devrimleri yapanlar teknolojiler değil, tam tersine teknolojileri kullanarak devrimleri yapanlar halklardir.

Çalışmasında nicel veri analizi ve nitel söylem analizi yöntemlerini birlikte kullanan Gerbaudo, Facebook sayfası yöneticileri ve kullanıcıları arasındaki duygusal bağı ortaya çıkarmaya çalışmıştır. Ona göre (2015: 254); siyasi Facebook sayfalarını yöneten aktivist yöneticiler tarafindan umut verici bir anlatı üretilmekte ve sıradan internet kullanıcıları, aktivist yöneticiler tarafından atılan mesajı güçlendirerek iş birliğini sağlamaktadır. Yöneticiler ve kullanıcılar arasındaki bu duygusal diyalog, kitlesel protesto katılımı için uygun psikolojik koşulların oluşturulmasına yardımcı olan bir duygusal bulaşma sürecini 
yaratmıştır. Bu durumu 'dijital coşku anları' olarak niteleyen Gerbaudo (2015: 254); kitlesel protesto seferberliğinde sosyal medyanın ve duygusal iletişimin belirli bir etkiye sahip olduğunu ve dijital çağda kolektif eylemin ortadan kalkma riskine dair bir yanıt sunduğunu belirtmektedir.

Tablo 8. Lin ve Margolin'in (2014) makale deseni

\begin{tabular}{|c|c|c|c|c|}
\hline$\underline{\text { AtIf }}$ & Makale İsmi & Alan & $\underline{\text { Amac }}$ & $\underline{\text { Öneriler }}$ \\
\hline 54 & $\begin{array}{l}\text { - The Ripple of } \\
\text { Fear, Sympathy and } \\
\text { Solidarity During the } \\
\text { Boston Bombings }\end{array}$ & $\begin{array}{l}\text { •Enformasyon } \\
\text { Bilimleri, } \\
\text { İletişim }\end{array}$ & $\begin{array}{l}\text { - Twitter kullanıcılarının } \\
\text { Boston maratonu } \\
\text { bombalamalarına tepki } \\
\text { olarak korku, sempati ve } \\
\text { dayanışma duygularını } \\
\text { nasıl ifade ettiklerini } \\
\text { incelemek }\end{array}$ & $\begin{array}{l}\text { - Paylaşılan korkuların } \\
\text { birden çok zaman } \\
\text { ve mekân ölçeğinde } \\
\text { nitelendirilmesi, bu }\end{array}$ \\
\hline 2014 & $\begin{array}{l}\text {-Yu-Ru Lin, } \\
\text {-Drew Margolin }\end{array}$ & $\begin{array}{l}\text { - Duygu } \\
\text { Analizi }\end{array}$ & $\begin{array}{l}\text { Sonuc } \\
\text { - Sosyal ağlarda korku } \\
\text { iletişim dinamikleri } \\
\text { ile insan hareketliliği } \\
\text { arasındaki bağlantılar, } \\
\text { enformasyon ve } \\
\text { duyguların nüfuslar } \\
\text { arasında yayılmasını } \\
\text { sağlamaktadır. }\end{array}$ & $\begin{array}{l}\text { tür bağlantıların daha } \\
\text { fazla araştırılması, kriz } \\
\text { yönetimi, enformasyon } \\
\text { yayılımı ve sosyal } \\
\text { bulaşma gibi alanlarda } \\
\text { incelenebilir. }\end{array}$ \\
\hline
\end{tabular}

Y1kıcı bir olayın toplumlar arası duyguları ve ifadeleri nasıl tetikleyebileceğini incelemek için ender bir fırsat sunduklarını düşündükleri Boston Maratonu bombalamasını örnek olay olarak alan Lin ve Margolin (2014), bu kapsamda Twitter'da yer alan 180 milyondan fazla tweeti incelemişlerdir. Duygu analizi yöntemini kullandıkları çalışmalarında Twitter API özelliğini kullanarak, \#prayforboston ve \#bostonstrong hashtaglerini kullanan kullanıcıların paylaştıkları içerikleri korku, sempati ve dayanışma olmak üzere üç farklı duygu kategorisine ayırmışlardır. Yazarlar araştırmada kullanılan korku ifadelerinin iki tür işlevi olduğu sonucuna varmışlardır: Birincisi korku, yayılma ve diğerleri tarafından hissedilmesi bağlamında etkili olmuştur. İkincisi korku aynı zamanda dayanışmanın ifadesi ile de doğrudan ilgilidir. Lin ve Margolin'e göre (2014: 27), topluluklardaki korku, doğrudan terörizmin hedef aldığg 1 bir toplulukla dayanışmaları uyandırmada üretken bir rol oynayabilmektedir. Bu bulgu, terörizmin genel beklentilerini sosyal medya çağında siyasi değişim için bir strateji olarak değerlendirmek açısından ilginçtir.

Çalışma, terör gibi kitlesel korkuya yol açan olaylarda kullanıcıların sosyal ağlarda ne tür içerikler paylaştığını göstermesi bakımından önemlidir. Ayrıca tweetlerin coğrafi kodlarının yer alması, Boston'a fiziksel mesafede yakın olanların ve şehri daha önce ziyaret edenlerin korku ve dayanışma ifadesinin en iyi öngörücüsü ve sempati ifadesinin en güçlü kullanıldığ 1 içerikler olduğu sonucuna varılmıştır. Araştırma sosyal ağlardaki etkinliklerin gerçek olaylar ve fiziksel yakınlıklardan bağımsız olmadığı sonucuna varmıştır. Lin ve Margolin'e göre (2014: 28); korku iletişim dinamikleri ile 
insan hareketliliği arasında ortaya çıkarılan bağlantılar, enformasyon ve duyguların popülasyonlar arasında yayılmasını anlamak açısından önemli sonuçlara sahiptir.

Tablo 9. Song ve diğerlerinin (2016) makale deseni

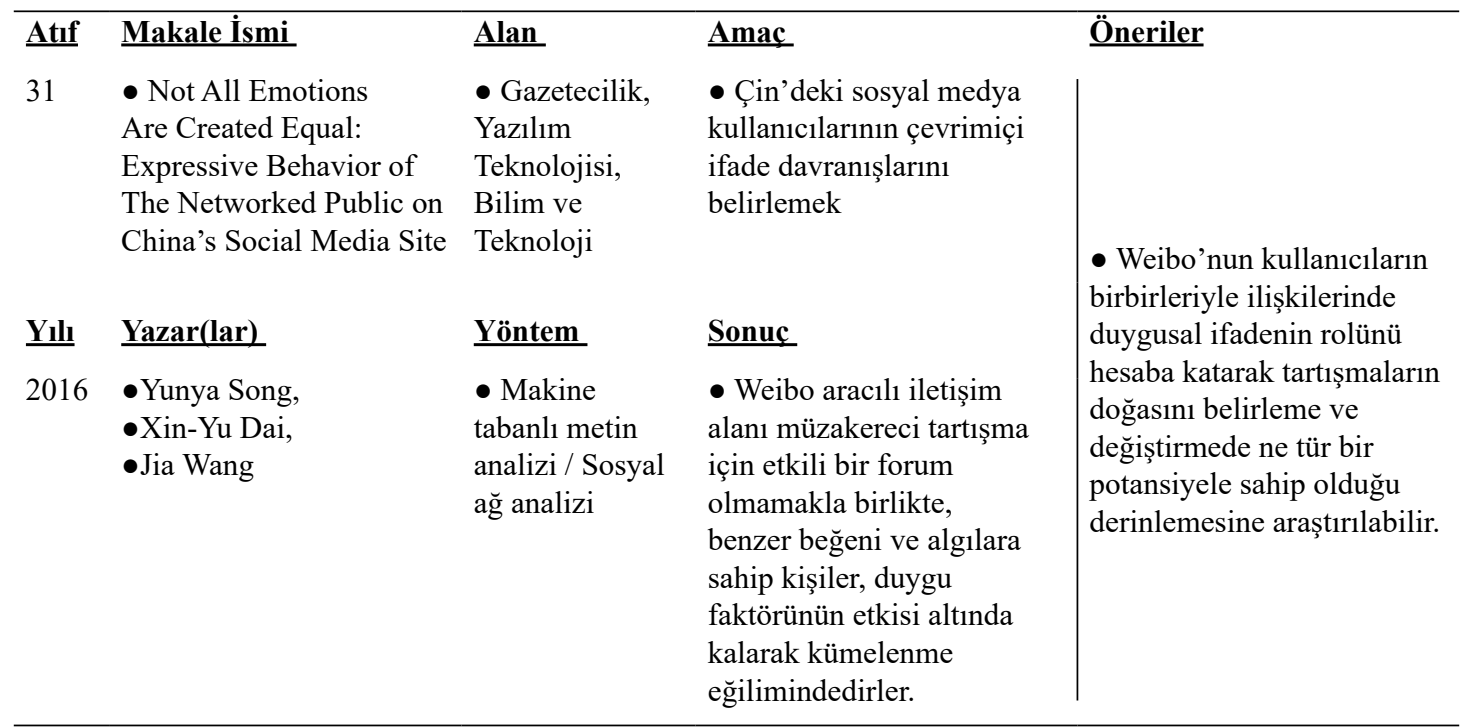

Çin'de kullanılan Twitter benzeri bir sosyal paylaşım ağı olan Weibo'yu inceleyen Song, Dai ve Wang (2016), sosyal medya kullanıcılarının çevrimiçi ifade davranışlarını araştırmışlardır. Gıda güvenliğinin politik yönleri etrafında oluşan tartışma ağının yapısını inceleyen yazarlar, Weibo'nun aracılı iletişim açısından müzakereci bir tartışma ortamına hizmet etmediğini, çünkü benzer düşünce yapısına sahip kişilerin bir araya gelme eğiliminde olarak duygu faktörünün baskın bir şekilde kullanıldığı sonucuna varmışlardır. Duygusal tartışmaların insanları bilişsel tartışmalardan daha fazla etkilediğini söyleyen Song, Dai ve Wang (2016: 525); öfke, korku, üzüntü gibi farklı duyguların farklı etkilere sahip olduğunu belirtmektedir.

Metin ve duygu analizinin birlikte kullanıldığ çalışmada, yazarlar sosyal ağların ağlaşmış yapısının, duygu açısından homofiliye yol açtı̆̆ını söylemektedir. Duygular açısından özellikle öfkenin diğer duygulardan daha hızlı ve daha geniş bir şekilde yayıldığını, ikinci sırada ise korku duygusunun geldiğini bulmuşlardır. Yazarlara göre öfke ve korku uyandıran içeriğin yayılma olasılı̆̆ diğer olumlu duygulardan daha yüksektir. Üzüntü uyandıran içeriğin ise halkın tepkisini tetikleme olasılığg daha düşük olarak çıkmıştır. Ayrıca kullanıcıların özelliklerinin incelendiği çalışmada, fazla takipçili olanların gönderilerinin az olanlara oranla daha hızlı ve daha geniş bir şekilde yayıldığı sonucuna varılmıştır. Araştırmacılar, bu tür sosyal ağların siyasi müzakereler söz konusu olduğunda etkili olduğunu düşünmekle birlikte, özellikle olumsuz duyguların yayılımı açısından tehlike arz ettiği konusunda hemfikirdirler. 
Tablo 10. Xiong ve diğerlerinin (2018) makale deseni

\begin{tabular}{|c|c|c|c|c|}
\hline$\underline{\text { AtIf }}$ & Makale Ismi & Alan & $\underline{\text { Amac }}$ & Öneriler \\
\hline 24 & $\begin{array}{l}\text { - An Emotional } \\
\text { Contagion Model For } \\
\text { Heterogeneous Social } \\
\text { Media with Multiple } \\
\text { Behaviors }\end{array}$ & $\begin{array}{l}\text { •Enformasyon } \\
\text { Teknolojisi, } \\
\text { Sağlık } \\
\text { Bilimleri, } \\
\text { Bilgisayar ve } \\
\text { Mühendisliği }\end{array}$ & $\begin{array}{l}\text { - Sosyal medyada } \\
\text { duygusal bulaşmanın } \\
\text { karş1lıklı etkileşimdeki } \\
\text { rolünü ortaya koymak }\end{array}$ & $\begin{array}{l}\text { - Alay veya ironi gibi } \\
\text { ifadeleri tetikleyen } \\
\text { karmaşık bağlamların } \\
\text { analiz yöntemi tarafından } \\
\text { kavranamaması, }\end{array}$ \\
\hline 2018 & $\begin{array}{l}\text { Yazar(lar) } \\
\text {-Xi Xiong, } \\
\text {-Yuanyuan Li, } \\
\text {-Shaojie Qia, } \\
\text { - Nan Han, } \\
\text { - Yue Wu, } \\
\text { - Jing Peng, } \\
\text {-Binyong Li }\end{array}$ & $\begin{array}{l}\text { •Duygu } \\
\text { Analizi }\end{array}$ & $\begin{array}{l}\text {-Sosyal ağlarda nihai } \\
\text { duygusal dağılım, ilk } \\
\text { duygusal dağılım ve } \\
\text { bulaşıcılıklara bağlıdır. }\end{array}$ & $\begin{array}{l}\text { duyguların } \\
\text { nitelendirilmesinde } \\
\text { belirsizliğe yol açtığı } \\
\text { için sonraki çalışmalarda } \\
\text { kullanılacak yöntemler } \\
\text { bu sorun göz önünde } \\
\text { bulundurularak } \\
\text { geliştirilebilir. }\end{array}$ \\
\hline
\end{tabular}

Sosyal ağlarda bireylerin iletişiminde duygunun ve duygusal bulaşıcılığın etkili olduğunun bulunduğu bir diğer çalışma Xiong ve diğerlerine (2018) aittir. Twitter'da duygu analizi yöntemiyle yapılan çalışmada, sosyal medyada duygusal bulaşıcılığın ayrıntılı sürecini ve özelliklerini göstererek, bireysel duygunun 'arkadaş'lık çerçevesinde sonraki duyguları etkileyebileceğini öngören duygusal bağımsız kademeli bir model önerilmiştir. Çalışmanın sonuçlarından bir tanesi homofilinin zıt duyguların kaybolmasına yol açabileceğidir. Bir kullanıcı tarafından gönderilen tweetin, arkadaşlarının sonraki duygularını etkileme kapasitesine sahip olduğu bulunmuştur.

Yazarlar (2018: 186), sosyal medyanın, kullanıcılar arasında iletişimi ve duygusal bulaşıcılığı kolaylaştıran çeşitli etkileşim mekanizmaları içerdiklerini ve aynı çevrimiçi topluluktan kullanıcıların genellikle ortak ilgi alanlarını paylaşmaları sebebiyle bu tür topluluklarda duygunun çok daha hızlı yayıldığını belirtmektedirler. Diğer çalışmalara benzer şekilde, bu araştırmada da depresyon, yalnızlık, öfke gibi olumsuz duyguların yayılmasının, mutluluk gibi olumlu duygulara göre daha kolay olduğu sonucuna varılmıştır. Aynı zamanda bir kullanıcının olumlu duygusu, arkadaşlarının olumsuz duyguları içeren ifadeleriyle bastırılabilmektedir. Belirli bir yakınlık içerisinde olan kullanıcıların seçtikleri kelimeler birbirlerine benzemekte, bu durum ise duygusal dili ifade eden kelimeler söz konusu olduğunda duygusal bulaşıcılığı arttırmaktadır. 


\section{Sonuç ve Öneriler}

Sosyal ağlarda enformasyonun dolaşımı ve yayılmasında duyguların göz ard1 edilemeyeceği gerçeği, yapılan çalışmaların bir sonucu olarak karşımıza çıkmaktadır. Duygusal bulaşıcılığı test edebilmek amacıyla büyük veri setleri ile çalışan araştırmacıların tamamı, kullanıcıların sosyal ağlardaki hareketlerini gerçekleştirirken duygulardan etkilendikleri sonucuna ulaşmışlardır. Araştırmaya dahil edilen 10 makalenin sonuçlarını şu şekilde değerlendirmek mümkündür:

- Duygular manipüle edilerek kullanıcıların olumlu ya da olumsuz duyguya sevk edilmeleri sağlanabilir.

- Duygular kutuplaşmaya sebep olur.

- Yankı odası etkisi kullanıcıların duygularını yönlendirir. edilemez.

- Yayılan duyguların etkisi kitlesel hareketler söz konusu olduğunda göz ard1

- Karşılıklı duygusal etkileşim kitlesel hareketin devamında etkilidir.

- Çeşitli terör olaylarında sosyal ağlar hem korku hem de dayanışmanın yayılmasını sağlar.

- Yankı odası etkisi duygu faktörünü etkili kılar.

- Homofili, kullanıcıların duygularının yönlendirilmesinde etkilidir.

- Olumsuz duyguların yayılma hızı daha yüksektir.

- Kullanıcılar olumlu duygulara sahip olsalar dahi, içinde bulundukları grup tarafından duyguları olumsuz bir yöne doğru evrilebilir.

Buna göre; sosyal ağlarda paylaşılan içeriklerin duygudan bağımsız olmadığını söylemek mümkündür. Kullanıcılar enformasyonu edinirken yahut paylaşırken dahil oldukları yakın çevrenin (aile, arkadaş, iş arkadaşı) içeriklerinin duygusal boyutundan etkilenmekte ve aynı zamanda sosyal ağlarda karşılaştıkları yakın olmayan çevrelerine ait içeriklerde olumsuz duyguların da etkisi altında kalabilmektedirler. Buna göre sosyal ağlarda dolaşıma sokulan içeriklerden duygu boyutunda etkilenebilmek için birbirine benzer gruplar içerisinde yer almak etkili olurken, aynı zamanda bunun bir gereklilik olmadığı gerçeğini de hesaba katmak gerekmektedir.

Facebook ve Twitter gibi kitleleri barındıran sosyal ağlarda, özellikle duygulara hitap eden kışkırtıcı ya da yönlendirici içerikler, kullanıcıların duygularını sabitlemeyi sağlamaktadır. Ancak bu durum betimlenirken, sosyal ağların mimari yapısının belirgin özelliklerinden olan 'benzerleri bir araya getirme' yaklaşımının sonucu olarak ortaya çıkan ve kutuplaşmaya yol açan yapısı göz ardı edilmemelidir.

$\mathrm{Bu}$ durum, kullanıcıların kendileriyle aynı düşünce ve duygularda olan kişilerle etkileşime girmesi ve onlardan etkileşim alması sonucunu doğurmaktadır. Ayrıca bu tür bir kullanım şekli yalnızca kullanıcıların inisiyatifiyle oluşmamakta, aynı zamanda 
sosyal ağların algoritmaları kullanılarak, çeşitli şekillerde yönlendirilmeleriyle de gerçekleşmektedir. Bu nedenle kullanıcıların, farklı görüşleri içeren, çeşitliliğin olduğu bir ortamda yer aldıklarında kendi kararlarını verebilmeleri daha sağlıklı olabileceğinden, yönlendirmeye daha az açık olma riskiyle karşılaşırlar. Bununla ilgili olarak, kullanıcıların aynı sesleri duymasına yol açacak bir balon içerisine hapsolmalarını engelleyebilmek için, farklı içeriklere denk gelmeyi kolaylaştırmak adına farklı görüşteki kişilerle etkileşime girmesi bir öneri olarak sunulabilir.

Araştırmaların etik boyutuna bakıldığında ise yalnızca bir araştırmanın büyük veriyle çalışırken karşılaşılan etik sorunları ele aldığı görülmektedir. Diğer çalışmalar, Facebook, Twitter ve Weibo tarafından sağlanan veri toplama araçlarını kullandıklarını belirtmiş ve kamuya açık olan verileri analiz ettikleri için etik bir sorun olmadığını vurgulamışlardır. Ancak İnternet Araştırmacıları Birliği'nin (Association of Internet Researchers - AoIR) 2019 yılında yayınlanan etik kodlarına göre; büyük verilerle çalışılsa dahi onanmış rıza almamak etik bir ikileme yol açmaktadır. Kimi araştırmacılar ilk-derece onanmış rızayı almakla birlikte, diğerleri kullanıcıların isimlerini silerek etik problemleri ortadan kaldırdıklarını düşünmektedirler. Kullanıcı isimleri paylaşılmasa dahi, incelenen çalışmaların bazılarında yer alan örnek tweet içerikleri, arama motorları vasıtasıyla tweetlerin sahibine kolayca ulaşmayı sağlamaktadır. $\mathrm{Bu}$ ise etik açıdan bir probleme işaret etmektedir (AoIR, 2019: 10).

Kramer ve diğerlerinin (2014) çalışmasının, kullanıcıların rızası olmadan içerikleri ve bunlara bağlı olarak duygularını manipüle etmelerinin ve bunun üniversite ve Facebook arasındaki iş birliğine dayanılarak yapılmış olmasının büyük yankı uyandırmasının ardından, araştırmacıların tamamının bu çalışmanın etik dışılığına atıf yaparak, içerikleri manipüle etmedikleri ve kendi çalışmalarının etik boyutunu bu şekilde oluşturduklarını vurguladıklarıgörülmüştür. Ancakbahsi geçen ağların veri toplamayöntemlerini kullanarak içeriklerin elde edilmesinin hem araştırmacılar hem de veriye ulaşmayı sağlayan ağlar açısından sorgulanması gerektiğini söylemek mümkündür. Zira kullanıcının içeriklerini kamuya açmasının, onların bir araştırmada kullanılmasını onayladığı anlamına gelmediği unutulmamalıdır. Aynı şekilde ağlara üye olarak birer kullanıcı olabilmek için onaylanması gereken kullanım sözleşmelerinin satır aralarında yer alan, kullanıcı gizliliğinin ihlalini içeren ifadelerin farkında olmak da yine kullanıcıların sorumluluğuna bırakılmaktadır. Araştırmacılar büyük veri setleri ile çalışırken kullanıcının kimliğini gizlemenin yanı sıra, araştırmaya rıza gösterip göstermediğini belirlemekle de yükümlüdürler. Bu noktada kullanıcılar sosyal ağlarda paylaştıkları içerikler nedeniyle çeşitli araştırmaların konusu haline gelebilmektedir. Bununla birlikte araştırmaya dahil edilen tüm çalışmalar sosyal ağların duygu pratiklerine ve performanslarına izin verdiklerini, bunun kullanıcıların bireysel tercihleriyle olabileceği gibi aynı zamanda etkileşime girilen diğer kullanıcılar vasıtasıyla da gerçekleşebileceğini belirtmişler, sosyal ağların yönlendirici doğasından ise neredeyse hiç bahsetmeyerek, bunların mimari yapılarının niteliklerini göz ardı etmişlerdir. Özellikle enformasyon kaynağı olarak kullanılan sosyal ağların, çeşitli algoritmalarla içerikleri yönlendirmeleri sebebiyle, bu ağlardaki duygunun boyutunun kullanıcılar açısından değil, ağların mimari yapıları açısından incelenmesine ihtiyaç vardır. 


\section{Kaynaklar}

Ahmed, S. (2014). Duyguların Kültürel Politikası, Çev. Sultan Komut, İstanbul: Sel Yayıncilik.

Alkan, V. (2017). Bir Sistematik Derleme Çalışması: 'Öğretmenlik Uygulaması'. Y1ldız Journal of Educational Research, 2(1), 1-23.

Association of Internet Researchers - AoIR (2019). Internet Research: Ethical Guidelines 3.0. https://aoir.org/reports/ethics3.pdf Erişim tarihi: 20.11.2020.

Baker, S. A. (2012). From The Criminal Crowd To The "Mediated Crowd": The Impact of Social Media on The 2011 English Riots. Safer Communities, 11(1), 40-49. https://doi.org/10.1108/17578041211200100

Barsade, S. G. (2002). The Ripple Effect: Emotional Contagion and Its Influence on Group Behavior. Administrative Science Quarterly, 47, 644-675. https://doi. org/10.2307/3094912

Baym, N. (2010). Personal Connections In The Digital Age. UK: Polity Press.

Berger, J. (2013). Contagious, Why Things Catch On. USA: Simon\&Schuster.

Binark, M. (2005). Kimlik(lenme), Dipnotsuz İletişim ve Etnik Laflama Odaları. M. Binark ve B. Kılıçbay (der.), İnternet-Toplum-Kültür, Ankara: Epos. s. 118-136.

boyd, d. (2011). Social Network Sites as Networked Publics: Affordances, Dynamics, and Implications. Z. Papacharissi (ed.), Networked Self, Identity, Community, and Culture on Social Network Sites, USA: Routledge, s. 39-58.

boyd, d. ve Ellison, N. B. (2007). Social Network Sites: Definition, History, and Scholarship. Journal of Computer-Mediated Communication, (13)1, 210-230. https:// doi.org/10.1111/j.1083-6101.2007.00393.x

Brady, W. J., Wills, A. J., Jost, J., T., Tucker, J., A. ve Bavel, J., V. (2017). Emotion Shapes The Diffusion of Moralized Content in Social Networks. PNAS, 114 (28), 73137318, https://doi.org/10.1073/pnas.1618923114

Conover, M. D., Ratkiewicz, J., Francisco, M., Gonçalves, B. Flammini, A. ve Menczer, F., (2011). Political Polarization on Twitter. Proceedings of the Fifth International AAAI Conference on weblogs and social media, http://www.leonidzhukov.net/hse/2015/ sna/papers/Conover_PoliticalPolarizationTwitter.pdf

Correa, D., Silva, L. A., Mondal, M., Benevenuto, F., Gummadi, K. P. (2015, 2629 May1s). The Many Shades of Anonymity: Characterizing Anonymous Social Media Content. Proceedings of the ninth international AAAI conference on web and social media, Oxford, England. https://www.aaai.org/ocs/index.php/ICWSM/ICWSM15/paper/ viewFile/10596/10490 
Danesi, M. (2017). The Semiotics of Emoji: The Rise of Visual Language In The Age of Internet. New York: Bloomsbury.

Dawkins, R. (2004). Gen Bencildir, Çev. Asuman Ü. Müftüoğlu, Ankara: TÜBİTAK Yayınları.

Del Vicario, M., Vivaldo, G., Bessi, a., Zollo, F., Scala, A., Caldarelli, G. ve Quattrociochhi, W. (2016). Echo Chambers: Emotional Contagion and Group Polarization on Facebook, Scientific Reports 6, 1-12, https://doi.org/10.1038/srep37825

Ellis, D. (2018). Social media, emoticons and process. T. Sampson, S. Maddison and D. Ellis (ed.), Affect and Social Media Emotion: Mediation, Anxiety and Contagion, London: Rowman\&Littlefield, s. 8-25.

Emojipedia. (2017). 5 Billion Emojis Sent Daily on Messenger, https://blog. emojipedia.org/5-billion-emojis-sent-daily-on-messenger/ Erişim tarihi: 14.11.2020.

Ferrara, E. ve Yang, Z. (2015). Measuring Emotional Contagion in Social Media. PLoS ONE 10(11), 1-14. https://doi.org/10.1371/journal.pone.0142390

Fowler, J. H. ve Christakis, N. A. (2008). Dynamic Spread of Happiness in a Large Social Network: Longitudinal Analysis Over 20 Years in The Framingham Heart Study, BMJ 337, 1-9, https://doi.org/10.1136/bmj.a2338

Frevert, U. (2018). Historicizing Emotions. Carolyn Price ve Eric A. Walle (Ed.). Emotion Researcher ISRE's Sourcebook for Research on Emotion and Affect (ss. 34-39) içinde. http://emotionresearcher.com/wp-content/uploads/2018/03/Emotion-ResearcherMarch-2018.pdf

Gerbaudo, P. (2015). Rousing The Facebook Crowd: Digital Enthusiasm and Emotional Contagion in The 2011 Protests in Egypt and Spain. International Journal of Communication 10, 254-273, http://ijoc.org/index.php/ijoc/article/view/3963

Gerbaudo, P. (2014). Twitler ve Sokaklar, Sosyal Medya ve Günümüzün Eylemciliği. Çev. Osman Akınhay, İstanbul: Agora Kitaplığı.

Goffman, E. (2017). Etkileşim Ritüelleri Yüz Yüze Davranış Üzerine Denemeler, Çev. Adem Bölükbaşı, Ankara: Heretik.

Gregg, M. (2012). White Collar Intimacy. A. Karatziogianni ve A. Kuntsman (ed.), Digital Cultures and The Politics of Emotion, London: Palgrave Macmillan, s.147-164.

Guntuku, S.C., Li, M., Tay, L. ve Ungar, L. H. (2019, 25-28 Haziran) Studying Cultural Differences in Emoji Usage Ccross The East and The West. Proceedings of the Thirteenth International AAAI Conference on Web and Social Media (ICWSM 2019), California, United States. https://arxiv.org/pdf/1904.02671.pdf

Hatfield, E., Cacioppo, J. T. ve Rapson, R. L. (1994). Emotional Contagion. UK: Cambridge University Press.

Hermida, A. (2014). Tell Everyone. USA: Penguin Random House Company. 
Hurlburt, G. F. (2018). Emoji: Lingua Franca or Passing Fancy?. IT Professional, 20(5), 14-19. https://doi.org/10.1109/MITP.2018.053891332

Instagram. (2015). Emojineering Part 1: Machine Learning for Emoji Trends. https://instagram-engineering.com/emojineering-part-1-machine-learning-for-emojitrendsmachine-learning-for-emoji-trends-7f5f9cb979ad Erişim tarihi: 14.11.2020.

Jothi, P. S., Neelamalar, M. ve Shakthi Prasad, R. (2011). Analysis of Social Networking Sites: A Study on Effective Communication Strategy in Developing Brand Communication. Journal of Media and Communication Studies, 3(7), 234-242.

Kaplan, A. M. ve Haenlein, M. (2010). Users of The World, Unite! The Challenges and Opportunities of Social Media. Business Horizons, 53, 59-68. https://doi.org/10.1016/j. bushor.2009.09.003

Kırık, A. M. ve Saltık, R. (2017). Sosyal Medyanın Dijital Mizahı: İnternet meme/ caps, Atatürk İletişim Dergisi (12), 99-118. https://dergipark.org.tr/en/download/articlefile/398240

Kimura-Thollander, P. ve Kumar, N. (2019, 4-9 May1s). Examining The "Global" Language of Emojis: Designing for Cultural Reprensentation. Proceedings of the 2019 CHI Conference on Human Factors in Computing Systems, Glasgow, UK. https://doi. org/10.1145/3290605.3300725

Koç Başaran, Y. (2017). Sosyal Bilimlerde Örnekleme Kuramı. Akademik Sosyal Araştırmalar Dergisi, 5(47), 480-495. http://dx.doi.org/10.16992/ASOS.12368

Kramer, A. D. I., G., J. E. ve Hancock, J. T. (2014). Experimental Evidence of Massive-Scale Emotional Contagion Through Social Networks. The Proceedings of the National Academy of Sciences (PNAS), 111(24), 8788-8790. https://doi.org/10.1073/ pnas. 1320040111

Lin, Y. R. ve Margolin, D. (2014). The Ripple of Fear: Sympathy and Solidarity During The Boston Bombings, EPJ Data Science, 3(1), 1-28. https://doi.org/10.1140/ epjds/s13688-014-0031-z

Marwick, A. E. ve boyd, d. (2010). I Tweet Honestly, I Tweet Passionately: Twitter Users, Context Collapse, and The Imagined Audience. New Media \& Society, 13 (11), 114-133.

Mayheim, A. (2008). What is Social Media?. iCrossing.

Newman, J. (2014). Sheryl Sandberg Apologizes for Facebook News Feed Experiment. https://time.com/2950888/facebook-news-feed-experiment-sorry/ Erişim tarihi: 20.11.2020.

Oberlo. (2020). Number of Twitter Users, https://www.oberlo.com/blog/twitterstatistics Erişim tarihi: 20.11.2020.

Onge, J. St. (2019). The Circulation of Rage, Memes and Donald Trump's Presidential Campaign. L. Zhang ve C. Clark (ed.), Affect, Emotion, and Rhetorical Persuasion in Mass Communication, UK: Routledge, s. 185-194. 
Öztürk, U. C. (2015). Bağlantıda Kalmak ya da Kalmamak İşte Tüm Korku Bu: İnternetsiz Kalma Korkusu ve Örgütsel Yansımaları. Uluslararası Sosyal Araştırmalar Dergisi, 8(37), 629-638. https://doi.org/10.17719/jisr.20153710629

Papacharissi,Z. (2009). The Virtual Geographies of Social Networks: AComparative Analysis of Facebook, LinkedIn and ASmallWorld, New Media\&Society,11(1\&2), 199220. https://doi.org/10.1177/1461444808099577

Pariser, E. (2011). The Filter Bubble What The Internet is Hiding From You. USA: The Penguin Press.

Parkinson, B., Fischer, A. H., ve Manstead, A. S. R. (2005). Emotion In Social Relations, Cultural, Group, and Interpersonal Processes. UK: Psychology Press.

Peretti, J. (2007). Notes on Contagious Media. J. Karaganis (ed.), Structures of Participation in Digital Culture, USA: Columbia University Press, s. 158-163.

Petticrew, M. ve Roberts, H. (2006). Systematic Reviews in The Social Sciences: A Practical Guide. USA: Blackwell Publishing.

Rodrigues, D., Prada, M., Gaspar, R., Garrido, M. V. ve Lopes, D. (2017). Lisbon Emoji and Emoticon Database (LEED):Norms For Emoji and Emoticons in Seven Evaluative Dimensions. Behavior Research Methods, 50, 1-14. https://doi.org/10.3758/ s13428-017-0878-6

Sampson, T. D. (2012). Virality, Contagion Theory In The Age of Networks. USA: University of Minnesota Press.

Sampson, T., Maddison, S. ve Ellis, D. (2018). Affect and Social Media: Emotion, Mediation, Anxiety and Contagion. London: Rowman\&Littlefield.

Schroeder, R. (2014). Big Data and The New World of Social Media Research, Big Data \& Society, 1-11, https://doi.org/10.1177/2053951714563194

Serrano-Puche, J. (2015). Emotions and Digital Technologies: Mapping The Field of Research in Media Studies. MEDIA@LSE Working Paper Series, 33, https://doi. org/10.13140/RG.2.2.31240.62729

Song, Y., Dai, X. Y. ve Wang, J. (2016). Not All Amotions are Created Equal: Expressive Behavior of The Networked Public on China's Social Media Site. Computers in Human Behavior, 60, 525-533, https://doi.org/10.1016/j.chb.2016.02.086

Statista. (2020). Number of Monthly Active Facebook Users Worldwide as of 3rd Quarter 2020. https://www.statista.com/statistics/264810/number-of-monthly-activefacebook-users-worldwide/ Erişim tarihi: 24.11.2020.

Sutton, S. ve Lawson, S. (2017). A Provocation for Rethinking and Democratising Emoji Design. Association for Computing Machinery, https://doi. org/10.1145/3064857.3079109

Sümer, B. (2011). The Importance of Literature Review in Research Design. I. Tomanic Trivundzka, N. Carpentier, H. Nieminen, P. Pruulmann-Venerfeldt, R. Kilborn, E. Sundin ve T. Olsson (Ed.), Critical Perspectives on The European Mediasphere, ECREA, s. 219-227. 
Tekrin, D. (2016, 26-27 Şubat). Kolektif Bir Kahkaha: İnternet Meme'leri. Yeni Medya Çalışmaları II. Ulusal Kongre, Alternatif Bilişim Derneği, 575-580. Elsevier.

Tettegah, S. Y. (2016). Emotions, Technology, and Social Media. Netherlands:

Thelwall, M., Buckley, K. ve Paltoglou, G. (2011). Sentiment in Twitter Events. Journal of the American Society for Information Science and Technology, 62 (2), 406418. https://doi.org/10.1002/asi.21462

Thrift, N. (2010). Understanding The Material Practices of Glamour. M. Gregg ve G. J. Seigworth (Ed.), The Affect Theory Reader, USA: Duke University Press, , s. 289308.

Toffler, A. (1980). The Third Wave. USA: William Morrow and Company.

Unicode. (2020). Full Emoji List v13.1. https://unicode.org/emoji/charts/full-emojilist.html Erişim tarihi: 14.11.2020.

Van Dijck, J. (2013). The Culture of Connectivity. UK: Oxford University Press.

Xiong, X., Li, Y., Qiao, S., Han, N., Wu, Y., Peng, J. ve Li, B. (2018). An Emotional Contagion Model for Heterogeneous Social Media with Multiple Behaviors. Physica A, 490, 185-202, https://doi.org/10.1016/j.physa.2017.08.025

Yardi, S. ve boyd, d. (2010). Dynamic Debates: An Analysis of Group Polarization Over Time on Twitter. Bulletin of Science, Technology and Society, 20, 1-8. https://doi. org/10.1177/0270467610380011

Yıldırım, S. ve Kişioğlu, A. N. (2018). Teknolojinin Getirdiği Yeni Hastalıklar: Nomofobi, Netlessfobi, Fomo. SDÜ T1p Fakültesi Dergisi, 25(4), 473-480. https://doi. org/10.17343/sdutfd.380640

Zhang, B. ve Vos, M. (2015). How and Why Some Issues Spread Fast in Social Media. Online Journal of Communication and Media Technologies, 5(1), 90-113. https:// doi.org/10.29333/ojcmt/2497 